\title{
Comparative genomics of host adaptive traits in Xanthomonas translucens pv. graminis
}

\author{
Lena Hersemann ${ }^{1}$, Daniel Wibberg ${ }^{2}$, Jochen Blom³ ${ }^{3}$ Alexander Goesmann ${ }^{3}$, Franco Widmer ${ }^{1}$, \\ Frank-Jörg Vorhölter ${ }^{2,4}$ and Roland Kölliker ${ }^{1 *}$ (D)
}

\begin{abstract}
Background: Xanthomonas translucens pathovars differ in their individual host ranges among Poaceae. As the causal agent of bacterial wilt in Italian ryegrass (Lolium multiflorum Lam.), X. translucens pv. graminis (Xtg) is one of the most important bacterial pathogens in temperate grassland regions. The genomes of six Xtg strains from Switzerland, Norway, and New Zealand were sequenced in order to gain insight into conserved genomic traits from organisms covering a wide geographical range. Subsequent comparative analysis with previously published genome data of seven non-graminis X. translucens strains including the pathovars arrhenatheri, poae, phlei, cerealis, undulosa, and translucens was conducted to identify candidate genes linked to the host adaptation of Xtg to Italian ryegrass.

Results: Phylogenetic analysis revealed a tight clustering of Xtg strains, which were found to share a large core genome. Conserved genomic traits included a non-canonical type III secretion system (T3SS) and a type IV pilus (T4P), which both revealed distinct primary structures of the pilins when compared to the non-graminis $X$. translucens strains. Xtg-specific traits that had no homologues in the other $X$. translucens strains were further found to comprise several hypothetical proteins, a TonB-dependent receptor, transporters, and effector proteins as well as toxin-antitoxin systems and DNA methyltransferases. While a nearly complete flagellar gene cluster was identified in one of the sequenced Xtg strains, phenotypic analysis pointed to swimming-deficiency as a common trait of the pathovar graminis.
\end{abstract}

Conclusion: Our study suggests that host adaptation of $X$. translucens pv. graminis may be conferred by a combination of pathovar-specific effector proteins, regulatory mechanisms, and adapted nutrient acquisition. Sequence deviations of pathogen-associated molecular patterns (PAMPs), as observed for the pilins of the T4P and T3SS, are moreover likely to impede perception by the plant defense machinery and thus facilitate successful host colonization of Italian ryegrass.

Keywords: Inter-pathovar comparison, Type VI secretion system, LPS O-antigen, HrpE, PilA

\section{Background}

Grasslands and pastures cover the largest agricultural area worldwide and serve as the prevalent source of roughage for ruminants in meat and milk production [1]. Bacterial wilt of forage grasses, caused by the bacterium Xanthomonas translucens pv. graminis (Xtg), is a serious issue in temperate grassland regions [2]. In the

\footnotetext{
* Correspondence: roland.koelliker@usys.ethz.ch

'Molecular Ecology, Agroscope, 8046 Zurich, Switzerland

Full list of author information is available at the end of the article
}

field, contaminated mowing tools are considered to be the primary source of inoculation and infected plants are easy to recognize by the characteristic withering of leaves and tillers as well as yellow stripes, occasionally occurring along the leaf blades [3]. Highly susceptible plants have been found to die within three weeks after inoculation, whereas less susceptible plants suffer from reduced regrowth and deformed inflorescences [2, 3]. $X t g$ is characterized by a wide host range, including species of the grass genera Lolium, Phleum, Festuca, 
Dactylis, and Trisetum [4]. Most pronounced, economic impact has been described for Xtg infections of Italian ryegrass (Lolium multiflorum), which represents an important source of fodder in dairy production [5]. With view on the high yield losses observed across infected plants, Xtg resistance is of major concern for breeding of new Italian ryegrass cultivars. The currently applied approach is based on recurrent phenotypic selection; however, reoccurrence of susceptible individuals after several selection cycles indicates the need for a detailed understanding of underlying pathogenicity mechanisms, which can be exploited in targeted breeding for bacterial wilt resistance $[6,7]$.

Pathogenic bacteria rely on virulence factors to (i) enter the host plant, (ii) to colonize it, and (iii) to overcome plant defense mechanisms. The latter are triggered by the perception of pathogen-associated molecular patterns (PAMPs) like flagellin and lipopolysaccharides (LPS), which can lead to the accumulation of antimicrobial substances and the release of reactive oxygen species $[8,9]$. To counteract these defense mechanisms, many bacteria rely on a type III secretion system (T3SS) in order to secrete effector proteins, which can interfere with plant cellular processes in favor of the pathogen [10]. It has been shown for $X$. campestris pv. vesicatoria that a functional T3SS is important for successful plant colonization and symptoms development [11]. Genome sequencing of the $X$. translucens pv. graminis strain Xtg29 revealed the presence of a non-canonical type III secretion system with deviations in gene order and sequence homology in comparison to the classical T3SS, which is well conserved among other Xanthomonas species [12]. Site-directed knockout mutagenesis of the main regulator HrpG and the structural components $\mathrm{HrpE}$ and HrcR in Xtg29 impaired bacterial virulence on Italian ryegrass, but the tested mutants were not affected in in planta colonization [12]. Therefore, it is likely that $\mathrm{Xtg}$ possesses further virulence factors, which crucially influence its pathogenicity on Italian ryegrass. Genome sequencing has long become the prevalent tool for gaining insight into putative virulence factors of plant pathogenic bacteria. The main objective of this study was the identification of virulence factors which enable Xtg to cause bacterial wilt in Italian ryegrass. We sequenced six $X t g$ strains collected in Switzerland, Norway, and New Zealand in order to identify the common core genome and shared virulence-related traits, which are conserved among Xtg strains from a wide geographical range. As many virulence-contributing factors represent hostindependent, common characteristics of plant pathogenic bacteria [13], we were further aiming to identify host adaptive traits by comparing the Xtg core genome with closely related strains, which are non-pathogenic on Italian ryegrass. For this, we exploited the close genetic relation of $X t g$ with other recently sequenced $X$. translucens strains with pathogenicity on either forage grasses (i.e. $X . t$. pv. arrhenatheri LMG 727, $X . t$. pv. poae LMG 728, and $X$. $t$. pv. phlei LMG 730) or cereals (i.e. $X$. t. pv. cerealis CFBP 2541, X. t. pv. undulosa Xtu4699, X. t. pv. translucens DSM 18974, and X. $t$. DAR61454) [14-18]. In contrast to $X t g$, the other three forage grass affecting pathovars are characterized by high host specialization to the plant species from which they have originally been isolated, i.e. Arrhenatherum elatius, Poa trivialis, and Phleum pratense [4]. The cereals affecting $X$. translucens strains, in turn, have primarily been described for their pathogenicity on barley, rye, and wheat $[18,19]$. Due to their close genetic relation and the distinct host specificity, the $X$. translucens pathovars represent an excellent system for studying host adaptation at the genome level.

\section{Methods}

\section{Strains, growth conditions, and DNA extraction}

Six Xanthomonas translucens pv. graminis (Xtg) strains were sequenced in this study (Table 1). The four Swiss strains were part of recent studies on genetic diversity of pv. graminis isolates from Switzerland [20]. Based on amplified fragment length polymorphism (AFLP) analyses, 28 out of 30 investigated $\mathrm{Xtg}$ isolates have been found to cluster into two major groups, which were significantly influenced by the geographic location of the corresponding sampling site. The Swiss strains were chosen as representatives of cluster I (Xtg9 and Xtg29), cluster II (Xtg2), and of strains not grouping in clusters (Xtg10). Two additional Xtg strains isolated in Norway (NCPPB 3709) and New Zealand (ICMP 6431) were obtained as freeze dried cultures from the National Collection of Plant Pathogenic Bacteria (Fera Science Ltd., Sand Hutton, United Kingdom) and the International Collection of Microorganisms from Plants (Landcare Research, Auckland, New Zealand), respectively. Unless otherwise stated, bacteria were cultivated at $28{ }^{\circ} \mathrm{C}$ on either GYC agar medium [20] or in $3 \mathrm{ml}$ CircleGrow ${ }^{\circ}$ broth (MP Biomedicals, Santa Ana, USA) in $15 \mathrm{ml}$ Falcon $^{\text {tw }}$ tubes (BD, New Jersey, USA) and by shaking at $200 \mathrm{rpm}$. For DNA extraction, the CTAB method [21] was used by applying modifications as described recently [16].

\section{Genome sequencing}

Whole genome sequencing was conducted for all Xtg strains listed in Table 1. In view of the sequencing costs, homopolymer resolution, and observed GC bias in library preparations [22, 23], we decided to apply the Illumina MiSeq System by sequencing $(2 \times 250 \mathrm{bp})$ paired-end libraries constructed with the TrueSeq DNA LT Sample Prep Kit (Illumina Inc., San Diego, United States). The Swiss strain Xtg29, which has previously 
Table 1 X.t. pv. graminis strains used for whole genome sequencing

\begin{tabular}{|c|c|c|c|}
\hline Strain & Host plant & Isolation site & Origin or reference \\
\hline$x \operatorname{tg} 29$ & Lolium multiflorum & Switzerland (Changins) & [20] \\
\hline Xtg2 & Lolium multiflorum & Switzerland (Beinwil) & [20] \\
\hline Xtg9 & Lolium multiflorum & Switzerland (Ellighausen) & [20] \\
\hline$X \operatorname{tg} 10$ & Lolium multiflorum & Switzerland (Ellighausen) & [20] \\
\hline NCPPB 3709 & Lolium perenne & Norway & $\mathrm{NCPPB}^{\mathrm{a}}$ \\
\hline ICMP 6431 & Lolium perenne & New Zealand & $\mathrm{ICMP}^{\mathrm{b}}$ \\
\hline
\end{tabular}

${ }^{a}$ NCPPB National Collection of Plant Pathogenic Bacteria

b ICMP International Collection of Microorganisms from Plants

been sequenced by applying the Roche 454 Genome Sequencer FLX System [12], was re-sequenced in order to prevent bias in comparative genome analysis due to deviating sequencing strategies. Genome assembly of Xtg29 was moreover facilitated by $(2 \times 250 \mathrm{bp})$ sequencing of an additional $8 \mathrm{~kb}$ mate-pair library on an Illumina MiSeq System (Illumina Inc., San Diego, United States). For the following comparative genome analysis, we used Xtg29 as our reference strain for Xtg.

\section{Assembly and annotation}

After sequencing, the raw data was processed with an in-house pipeline including CASAVA version 1.8 as described recently [24]. The de novo genome assembly of all strains was conducted with the GS de Novo Assembler software version 2.8 with default settings (Roche, Basel, Switzerland). Genomes were annotated using an in-house pipeline based on the workflow engine Conveyor [25]. This pipeline uses Prodigal [26], RNAMMER [27] and ARAGORN [28] for the prediction of coding sequences, rRNAs, and tRNAs. Functional annotation is realized by a comparison of predicted coding sequences against a database of conserved orthologous groups of the genus Xanthomonas identified by the EDGAR software [29]. Genes that could not be annotated by this approach were compared to a collection of sequence databases comprising Swissprot, Refseq, and Pfam-A [30-32].

\section{Genome comparisons}

Publically available genome data of seven non-graminis $X$. translucens strains were used for comparative genome analysis (Table 2). In order to facilitate data comparability, the assemblies of all non-graminis strains were annotated de novo by using the same strategy as described above. Assignments of the four forage grass affecting $X$. translucens pathovars (i.e. pv. arrhenatheri, pv. graminis, pv. poae, and pv. phlei) to the graminis group followed the denomination by Vauterin et al. [33].

Comparative genome analysis was performed using EDGAR 2.0 [29]. The platform employs a bit score related cutoff value, which is generated based on BLAST score ratio values (SRVs) to identify orthologous genes. Thus, coding sequences (CDS) from different genomes are considered orthologous, if the predicted SRV exceeds the calculated cutoff. This approach allows the identification of real orthologues as representatives of the calculated core genomes. In contrast, only CDS without any hit against any of the other genomes are considered as true singletons [34]. EDGAR 2.0 was used for the calculation of core and pan genomes across the $X$. translucens strains and true singleton prediction as well as for the construction of a core genome based phylogenetic tree. Therefore, coding sequences conserved among all analyzed genomes were aligned using MUSCLE [35], concatenated, and used to create a phylogeny using Kimura distances and the neighbor-joining method as implemented in the PHYLIP package [36]. Additionally, average nucleotide identities (ANI) of the orthologous

Table 2 Xanthomonas genomes used for comparative genome analysis

\begin{tabular}{|c|c|c|}
\hline Strain $^{a}$ & Accession number & Reference \\
\hline X. translucens pv. graminis Xtg29 & PRJEB10857 & this study \\
\hline X. translucens pv. graminis Xtg2 & PRJEB10858 & this study \\
\hline X. translucens pv. graminis Xtg9 & PRJEB10859 & this study \\
\hline X. translucens pv. graminis Xtg10 & PRJEB10860 & this study \\
\hline X. translucens pv. graminis NCPPB 3709 & PRJEB10862 & this study \\
\hline X. translucens pv. graminis ICMP 6431 & PRJEB10861 & this study \\
\hline X. translucens pv. graminis CFBP $2053^{\mathrm{PT}}$ & PRJNA290469 & {$[47]$} \\
\hline X. translucens pv. arrhenatheri LMG $727^{\mathrm{PT}}$ & PRJEB9902 & {$[16]$} \\
\hline X. translucens pv. poae LMG $728^{\mathrm{PT}}$ & PRJEB9904 & {$[16]$} \\
\hline X. translucens pv. phlei LMG $730^{\mathrm{PT}}$ & PRJEB9905 & {$[16]$} \\
\hline X. translucens pv. cerealis CFBP $2541^{\mathrm{PT}}$ & PRJNA268946 & {$[14]$} \\
\hline X. translucens pv. undulosa Xtu4699 & PRJNA248137 & {$[15]$} \\
\hline $\begin{array}{l}\text { X. translucens pv. translucens } \\
\text { DSM } 18974^{\top}\end{array}$ & PRJEB647 & {$[17]$} \\
\hline X. translucens DAR61454 & PRJNA169523 & {$[18]$} \\
\hline X. oryzae pv. oryzae PXO99A & PRJNA28127 & {$[82]$} \\
\hline
\end{tabular}

${ }^{a}$ Pathotype strains $\left({ }^{\mathrm{PT}}\right)$ and the $X$. translucens type strain $\left({ }^{\mathrm{T}}\right)$ are indicated 
genes of the core genome [37] were calculated using EDGAR 2.0.

\section{Singleton and gene cluster analysis}

Identification and characterization of the virulencecontributing gene clusters and the predicted singletons was conducted by a combined approach of BLASTP analysis [38], conserved domain search [39], and signal peptide prediction by SignalP 4.0 [40]. Moreover, plantinducible promoter (PIP) boxes [41] were identified by regular expression search as described recently [12]. Class III signal peptides in type IV pilin sequences were identified based on the core motif [GAS]-[ACFGILMNPQSTVWY]4-[DE] as reported by Imam et al. [42]. Taking the obtained results into account, annotation of the gene region and/or gene function was manually revised when considered appropriate. Analysis of the assembly gap observed for two neighboring, predicted singletons of the Xtg core genome was done using Sanger sequencing. Therefore, we amplified the gap-spanning region in $20 \mu \mathrm{l}$ reaction volumes adjusted with $\mathrm{ddH}_{2} \mathrm{O}$ and containing $20 \%(v / v) 5 \times \mathrm{GC}$ buffer, $3 \%$ $(v / v)$ DMSO, $0.05 \mathrm{mM}$ of each dNTP, $0.2 \mu \mathrm{M}$ forward primer (AGGCGTGTGGAAACGCACTG), $0.2 \mu \mathrm{M}$ reverse primer (CCAGTGGCGTGATCTTCACC), 50 ng genomic DNA of Xtg29, and 0.4 U Phusion Hot Start II DNA polymerase (Thermo Fisher Scientific, Waltham, USA). Thermocycler conditions were set to initial denaturation for $1 \mathrm{~min}$ at $98^{\circ} \mathrm{C}, 30$ cycles of denaturation for $10 \mathrm{~s}$ at $98^{\circ} \mathrm{C}$, annealing for $10 \mathrm{~s}$ at $64{ }^{\circ} \mathrm{C}$, and elongation for $15 \mathrm{~s}$ at $72{ }^{\circ} \mathrm{C}$, followed by one final elongation for $7 \mathrm{~min}$ at $72{ }^{\circ} \mathrm{C}$. The obtained PCR product was purified with the NucleoSpin ${ }^{\circ}$ Gel and PCR Clean-up kit (Macherey-Nagel, Düren, Germany). Sequencing was performed with the the BigDye ${ }^{\circ}$ Terminator v3.1 Cycle Sequencing Kit and the ABI Prism 3130xl Genetic Analyzer following the manufacturer's recommendations (Applied Biosystems, Foster City, USA).

\section{Pathogenicity assay}

All six Xtg strains listed in Table 1 were verified for pathogenicity on the Italian ryegrass (Lolium multiflorum) genotype LmK-01 [43] using four weeks old, clonally propagated plants with five to ten tillers each. The bacteria were grown over night in liquid medium containing $2 \%(w / v)$ glucose and $0.5 \%(w / v)$ yeast extract at $28{ }^{\circ} \mathrm{C}$ and $200 \mathrm{rpm}$. Cells were harvested by centrifugation for $5 \mathrm{~min}$ at $6500 \mathrm{~g}$, resuspended in $0.8 \%(w / v)$ sodium chloride and diluted to a final density of $\mathrm{OD}_{580 \mathrm{~nm}}=0.3$, corresponding to $9 \times 10^{8}$ colony forming units per ml. Inoculation was conducted by cutting the plants with scissors dipped into the bacterial suspensions. As a negative control, sterile aqueous $0.8 \%(w / v)$ sodium chloride solution was used. Per treatment, four pots with one plant each were inoculated. Assessment of symptoms development was performed 28 days post inoculation (dpi) and was based on a scoring system of nine indices representing disease severity in ascending order from no symptoms (1), over quantitative increasing wilting symptoms on leaves and tillers to finally dead plants (9) [43]. Analysis of variance and predefined contrasts implemented in R statistical software [44] were used to test for significant differences between the control treatment and the bacterial strains.

\section{Motility assay}

Motility assays were performed on TY agar medium containing $0.5 \%(w / v)$ tryptone, $0.3 \%(w / v)$ yeast extract, 0.07\% (w/v) calcium chloride, and 0.3\% (w/v) BactoTM Agar (Becton, Dickinson and Company, Sparks, USA). Bacterial colonies, grown on solid GYC agar medium, were transferred by a toothpick to the center of the TY agar surface. Spreading of the individual colonies was photographically documented after ten days incubation time at $28{ }^{\circ} \mathrm{C}$.

\section{Results}

\section{Genome sequencing of $X$. t. pv. graminis strains}

Whole genome sequence data were determined for six Xtg strains (Xtg29, Xtg2, Xtg9, Xtg10, NCPPB 3709, and ICMP 6431), as a prerequisite for subsequent comparative analysis (Additional file 1: Table S1). The obtained number of contigs ( $>500 \mathrm{bp}$ ) varied from 349 for ICMP 6431 to 369 for Xtg29 with an average N50 contig length of $18,459 \mathrm{bp}$. Genome data based on sequencing of single paired-end libraries only, revealed 284 to 296 scaffolds, while the combination with mate-pair sequencing data, as applied for Xtg29, reduced the number of scaffolds to three. In contrast, a previous Xtg29 assembly had 788 contigs (> $500 \mathrm{bp}$ ) and 12 scaffolds upon sequencing with the 454 FLX System [12]. De novo annotation of the 454 assembly by using the same strategy as applied in the present study, revealed 3619 predicted coding sequences (CDS) while 3543 CDS were identified for the Illumina MiSeq-based assembly of the resequenced Xtg29 genome (Additional file 2: Table S2). Differing annotation and assembly parameter reflect the technological progress manifest in current Illumina sequencing techniques compared to previous 454-based methods.

\section{$X t g$ strains differed in their genome size from other $X$. translucens pathovars}

All seven Xtg strains were characterized by a reduced genome size when compared against the non-graminis $X$. translucens strains (Table 3). The six Xtg strains, sequenced in this study, further revealed a distinctly smaller number of predicted CDS (3487 to 3553 CDS) in 


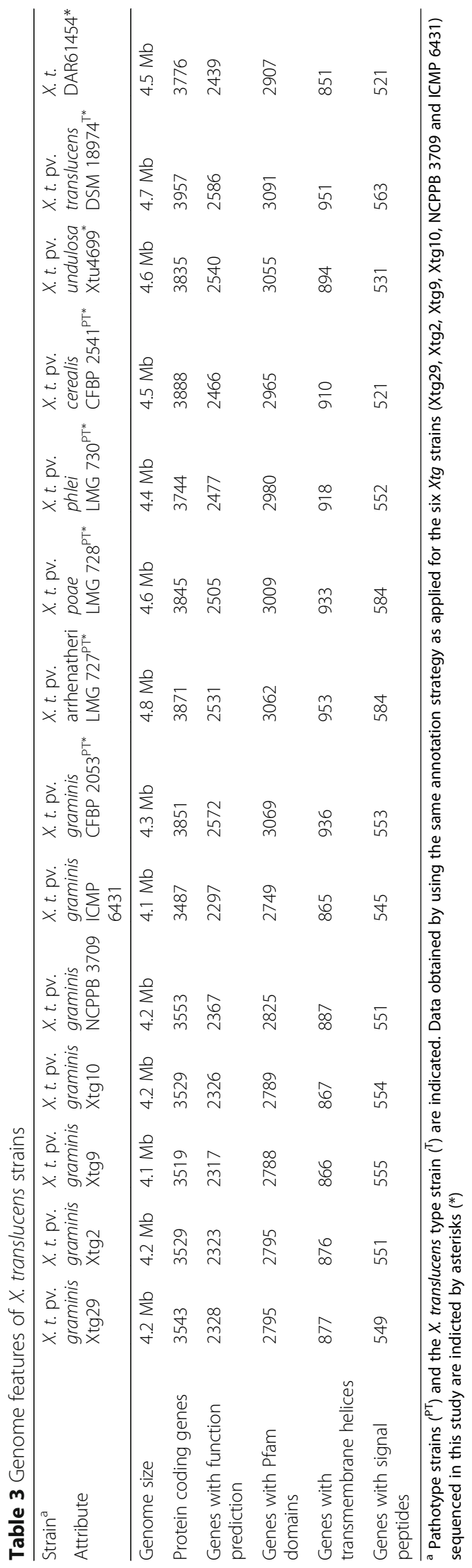


comparison to 3776 to 3957 CDS predicted for the other $X$. translucens strains including the pv. graminis pathotype strain CFBP 2053.

\section{Inter-pathovar phylogeny of the species $X$. translucens revealed a close genetic relation of $X t g$ strains}

Phylogenetic analysis was carried out based on the amino acid (AA) sequences of orthologous CDS conserved among the different $X$. translucens pathovars, using the rice pathogen $X$. oryzae pv. oryzae PXO99A as an outgroup. In the resulting phylogenetic tree, the four forage-grass affecting $X$. translucens pathovars of the graminis group were separated from cereals-affecting $X$. translucens strains (Fig. 1). Furthermore, we found all $X t g$ strains including the pathotype strain CFBP 2053 to cluster tightly together. Across those, no distinct intrapathovar differences were observed.

Similar results were observed for the calculated average nucleotide identities (ANI). Thus, the forage-grass affecting $X$. translucens pathovars, i.e. pv. arrhenatheri, pv. poae, pv. phlei, and pv. graminis shared ANI values of 97.33 to $98 \%$ when compared among each other, but revealed only 95.3 to $95.99 \%$ ANI with the cerealsaffecting $X$. translucens strains (Fig. 2). While also the non-graminis strains $X . t$. pv. translucens DSM 18974, X. t. pv. undulosa Xtu4699, and $X$. $t$. DAR61454 were found to possess ANI values of 97.74 to $99.67 \%$, highest average nucleotide identities of 99.9 to $99.97 \%$ were observed for the seven Xtg strains.

\section{All Xtg strains caused bacterial wilt on Italian ryegrass (Lolium multiflorum)}

Prior to detailed genome-based comparison, we analyzed the Xtg strains sequenced in this study for their pathogenicity on Lolium multiflorum ( $\mathrm{Lm}$ ). Clear wilting symptoms were found on all $L m$ plants inoculated with any of the six Xtg strains four weeks after clipping inoculation (Fig. 3); however, disease severity varied between the individual strains. Most pronounced symptoms with average wilting scores of 5.5, 7.25, 6.25, and 6 were observed for the four Swiss strains, i.e. Xtg2, Xtg9, Xtg10, and Xtg29. In contrast, only moderate symptoms were found for the two strains collected in Norway (NCPPB 3709) and New Zealand (ICMP 6431), reflected by average scores of 3 and 3.25, respectively. It is noticeable, that replicates of the less aggressive strains showed clearly lower variance of at most one score difference than observed for the Swiss strains, which varied over a range of up to four scores. Nevertheless, variance analysis indicated statistically significant differences in virulence $(p<0.01)$ between the Swiss strain Xtg29 and NCPPB 3709 and ICMP 6431, respectively.

With regard to the detected differences in virulence, we performed whole genome comparison of the Xtg strains from different geographical locations. However, we did not find any orthologues shared by the Swiss strains (i.e. Xtg29, Xtg2, Xtg9, and Xtg10) but absent in the strains isolated in Norway (NCPPB 3709) and New Zealand (ICMP 6431), respectively (Additional file 3: Figure S1). Likewise, no CDS were found to be exclusively conserved in NCPPB 3709 and ICMP 6431.

\section{Intra-pathovar comparison of Xtg strains revealed a flagellar gene cluster and a type VI secretion system as strain-specific traits}

For intra-pathovar comparison of the Xtg strains, 1 (Xtg10) to 67 (NCPPB 3709) strain-specific CDS were predicted (Additional file 4: Figure S2). With the exception of NCPPB 3709, most of these predicted singletons represented hypothetical proteins with the highest number of 27 CDS observed for the pathotype strain CFBP 2053. This strain was further characterized by nine transposases identified along with 28 identical paralogous genes, while no transposases were present in the singletons predicted for the other Xtg strains. The Norwegian strain NCPPB 3709 was found to encode 38 homologues of a flagellar gene cluster and six chemotaxis proteins, which revealed no homologous genes in the other six Xtg strains. However, a motility assay on $0.3 \%$ agar medium revealed swimming deficiency not just for Xtg29 and ICMP 6431, but also for NCPPB 3709 in comparison to the swimming ability observed for pv. arrhenatheri, pv. poae, and pv. phlei pathotype strains (Fig. 4). Comparison of the flagellar gene cluster of NCPPB 3709 and the pv. arrhenatheri pathotype strain LMG 727 revealed the absence of fliJ and a truncated $f l i K$ for the $X t g$ strain (Fig. 5). For Xtg2, two singletons were found to be homologous to genes of a type VI secretion system (T6SS) gene cluster. Additional, 11 T6SS genes, which were identified in the Xtg2 genome, had also homologues in Xtg9, Xtg10 and NCPPB 3709 (Additional file 5: Table S3). For the genomes of Xtg29 and ICMP 6431, no T6SS homologues were observed.

\section{Xtg strains shared a large core genome}

All $X t g$ strains were found to share a large common core genome of 3333 CDS. Thus, $86.17 \%$ of the predicted pan genome (3868 CDS) was conserved among the seven Xtg strains including the pathotype strain CFBP 2053. Various virulence-contributing gene clusters were identified in the Xtg core genome, i.e. gene clusters of lipopolysaccharide biosynthesis, xanthan biosynthesis, type I secretion system (T1SS), xps type II secretion system (T2SS), the non-canonical type III secretion system (T3SS) as well as the regulatory rpf gene cluster of pathogenicity factor synthesis (Table 4). Moreover, we identified 22 homologues of the type IV pilus (T4P) (Additional file 6: Table S4). The major pilin PilA was 


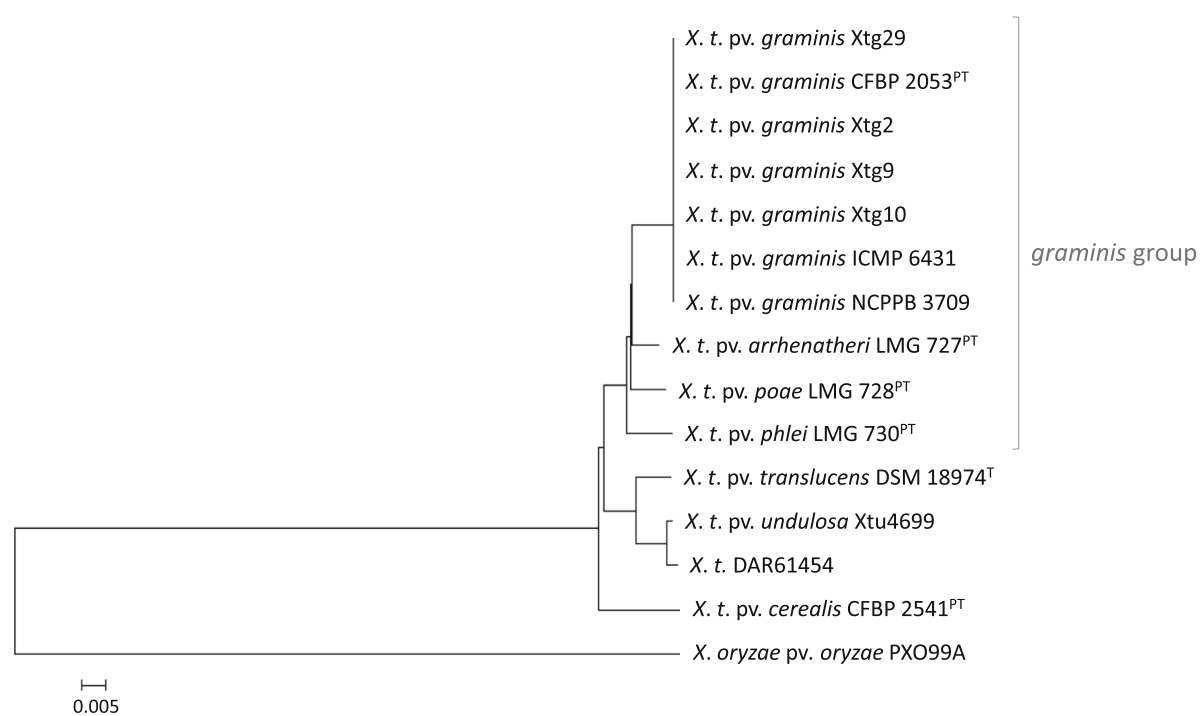

Fig. 1 Phylogeny of $X$. translucens pathovars. The calculated phylogenetic tree was based on the amino acid sequences of CDS conserved among 15 genomes from seven pv. graminis strains, seven non-graminis X. translucens strains, and X. oryzae pv. oryzae PXO99A as an outgroup. Pathotype strains $\left({ }^{P T}\right)$ and the $X$. translucens type strain ( $\left(^{\top}\right)$ are indicated. In total, 32,220 coding sequences (2148 per genome) with 11,474,880 amino acid residues (764,992 per genome) were used for the construction of the tree using the neighbor-joining method. In 500 iterations all branches showed at least $56.2 \%$ bootstrapping support (Additional file 11: Figure S6)

not predicted by the intrinsic gene prediction tool Prodigal, but analysis of the $1.5 \mathrm{~kb}$ DNA region between neighboring pilC gene and a putative transposase gene using the ExPASy translate tool predicted a 411 bp gene with a PilA COG domain (E-value: $2.45 \times$ $\left.10^{-20}\right)$. This gene was further found to possess the characteristic class III signal peptide, which was likewise identified for the minor T4P pilins PilX, PilW, PilV, and FimT. Also PilE revealed a corresponding signal peptide after manual shifting of the translational start site.

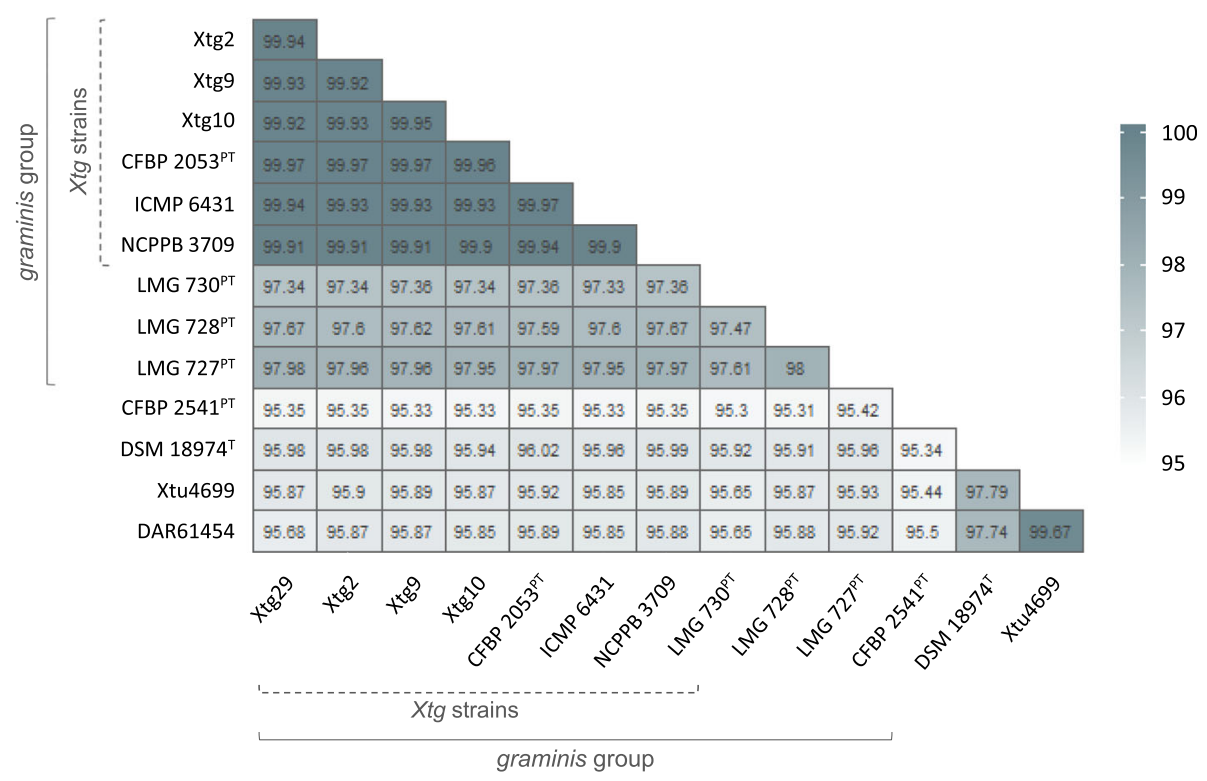

Fig. 2 Average nucleotide identities of $X$. translucens pathovars. The data represent the mean percentage identities of orthologues shared by seven pv. graminis strains (i.e. Xtg29, Xtg2, Xtg9, Xtg10, ICMP 6431, NCPPB 3709, and CFBP 2053) as well as seven non-graminis strains representing different $X$. translucens pathovars (i.e. X. t. pv. arrhenatheri LMG 727, X. t. pv. poae LMG 728, X. t. pv. phlei LMG 730, X. t. pv. undulosa Xtu4699, X. t. pv. cerealis CFBP 2541, X. t. pv. translucens DSM 18974, and X. t. DAR61454). Pathotype strains $\left({ }^{\mathrm{PT}}\right)$ and the $X$. translucens type strain $\left({ }^{\top}\right)$ are indicated 


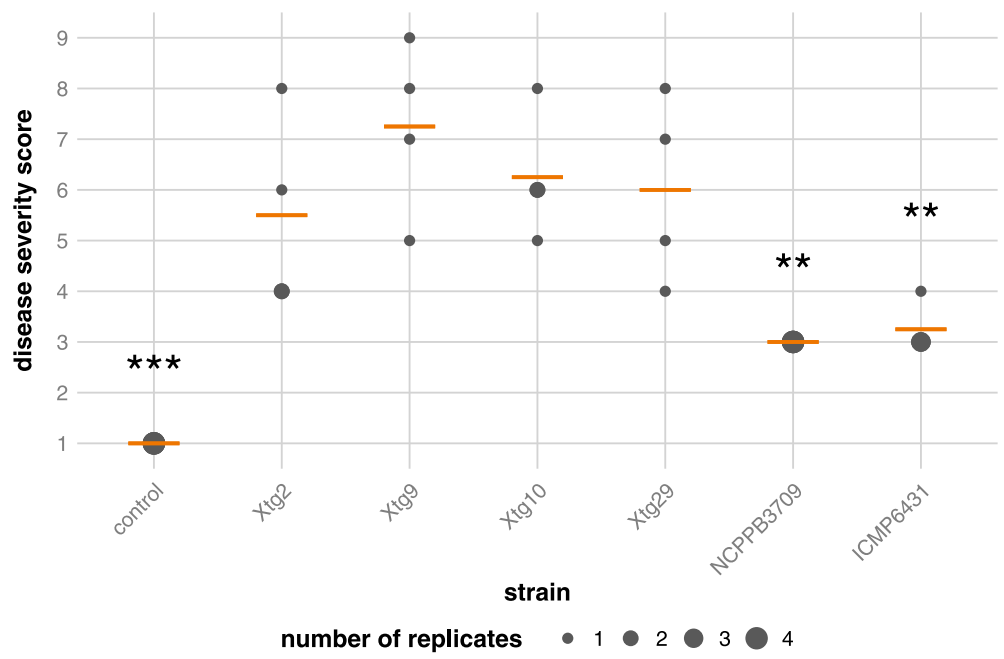

Fig. 3 Pathogenicity of forage grass affecting $X$. translucens pv. graminis strains on Italian ryegrass (Lolium multiflorum). Disease severity scores for bacterial wilt ranging from no symptoms (1) to dead plants (9) were evaluated 28 days post infection for four replicates per tested strain. Size of dots indicates the number of replicates allocated to a particular score, each represented by one clonal replicate of the L. multiflorum genotype LmK-01. Orange bars indicate the mean over the four replicates. The six tested strains of Xtg originated from different geographical locations, i.e. Switzerland (Xtg2, Xtg9, Xtg10, and Xtg29), Norway (NCPPB 3709) and New Zealand (ICMP 6431). Asterisks indicate significant differences in comparison to $X \operatorname{tg} 29(* * * 0.001 ; * * 0.01)$

While all identified virulence-contributing gene clusters were found to be largely conserved across the seven $X t g$ strains, slight intra-pathovar variations were observed for the gene clusters of xanthan and LPS biosynthesis. Thus, we identified a gene fusion of gumK and gumL in the gum gene cluster of xanthan biosynthesis in the NCPPB 3709 genome. Additionally, the Xtg genomes showed slight genomic variance within the putatively $\mathrm{O}$ antigen encoding region of the LPS gene cluster between etfA (XTGART29_0580) and metC (XTGART29_0559). The observed differences derived from gene separation events due to nonsense mutations in two individual genes.

\section{Variations in surface exposed structures distinguished Xtg} strains from other $X$. translucens pathovars

Comparison of the non-canonical type III secretion system (T3SS) of the non-graminis $X$. translucens strains with the one identified in Xtg29, revealed significant differences in AA sequence identity (Fig. 6). High percentage sequence similarity was observed for 21 out of the 22 T3SS genes (AA identity $>75 \%$ ). In contrast, the
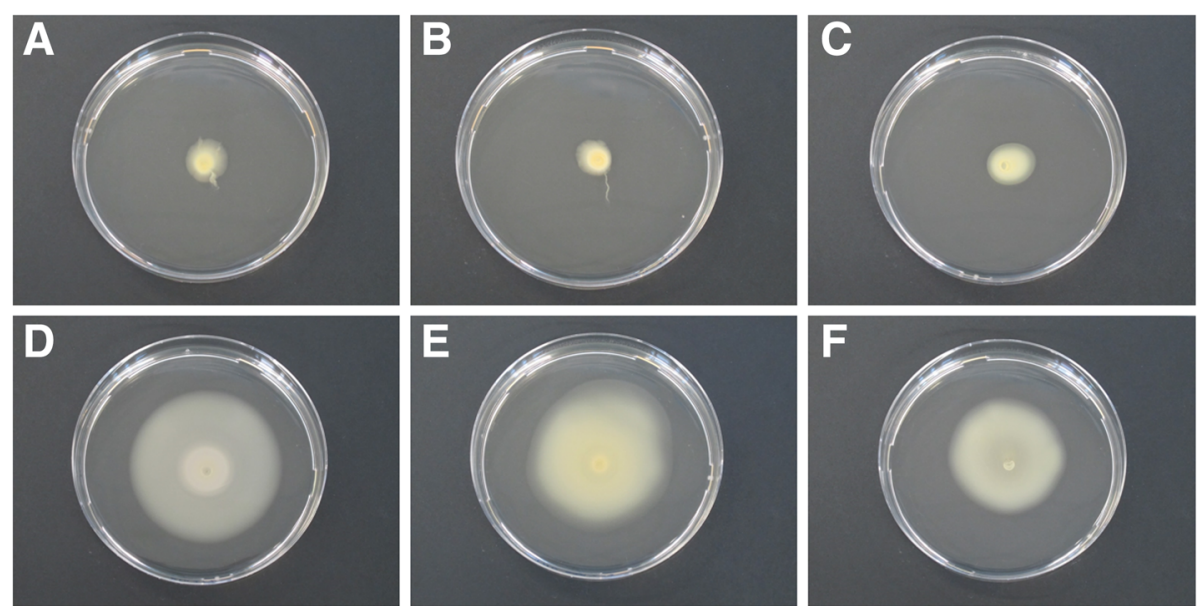

Fig. 4 Motility assay of $X$. translucens pathovars on soft agar. Absence and presence of flagellar-mediated swimming motility of three $X$. t. pv. graminis strains, i.e. Xtg29 (a), NCPPB 3709 (b), and ICMP 6431 (c) as well as X. t. pv. arrhenatheri LMG 727 (d), X. t. pv. poae LMG 728 (e), and X. t. pv. phlei LMG 730 (f) after incubation for 10 days at $28^{\circ} \mathrm{C}$ 


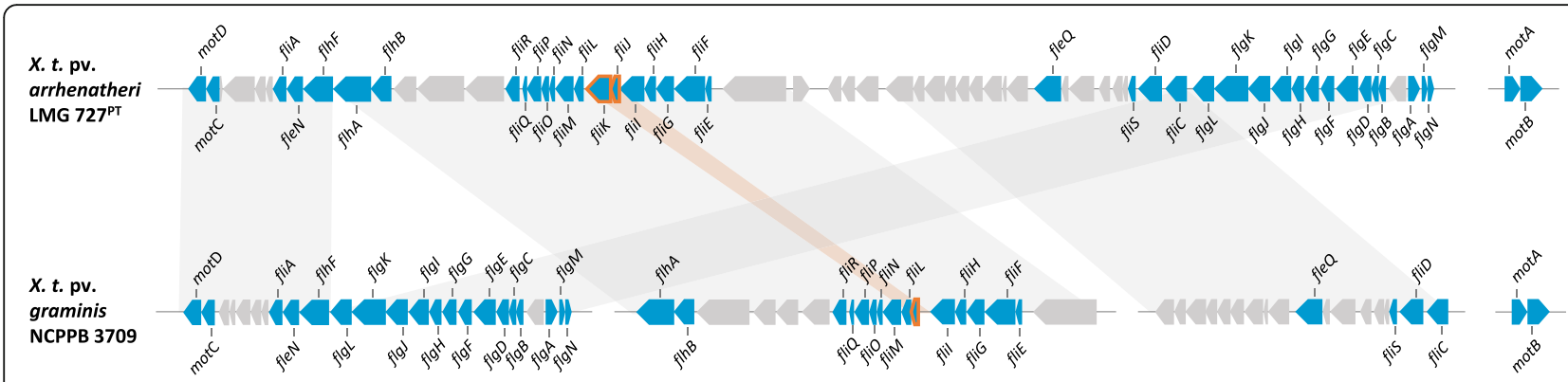

Fig. 5 Comparison of the flagellar gene cluster of X.t. pv. arrhenatheri LMG 727 and X. t. pv. graminis NCPPB 3709. Without motA and motB, the illustrated flagellar gene cluster of LMG 727 spanned a region of 68.77 kb comprising 65 coding sequences. Grey patches emphasized the observed rearrangement of the corresponding gene cluster in NCPPB 3709. Genes encoding for structural components of the flagellum (fli, fle, flg, flh) and components of the motor complex, i.e. $\operatorname{mot} A, \operatorname{mot} B, \operatorname{mot} C$, and motD are illustrated by blue coloration. Among those, regions with significant differences are highlighted by orange borders

HrpE pilin of the non-graminis strains revealed only 52.58 to $65.98 \%$ amino acid sequence identity when compared to Xtg29. A multiple sequence alignment unraveled further inter-pathovar differences of HrpE. We found less than $75 \%$ sequence identity of the corresponding homologues across the different $X$. translucens strains with the exceptions of LMG 727 and LMG 730 (96.91\% AA identity), DSM 18974 and CFBP 2541 (97.94\% AA identity), and DAR61454 and Xtu4699 (100\% AA identity). The multiple sequence alignment further revealed the $\mathrm{N}$-terminus as the most variable

Table 4 Virulence-related gene clusters identified in X. t. pv. graminis strains

\begin{tabular}{|c|c|c|}
\hline Gene cluster & Genomes $^{\mathrm{a}}$ & Reference \\
\hline type I secretion system & core genome & [83] \\
\hline type II secretion system & core genome & [84] \\
\hline $\begin{array}{l}\text { type III secretion system, non- } \\
\text { canonical }\end{array}$ & core genome & {$[12]$} \\
\hline type VI secretion system & $\begin{array}{l}X \operatorname{tg} 2, X \operatorname{tg} 9^{*}, X \operatorname{tg} 10^{*}, N C P P B \\
3709^{*}\end{array}$ & [51] \\
\hline type IV pilus & core genome & [59] \\
\hline flagellum & NCPPB 3709 & [85] \\
\hline $\begin{array}{l}\text { regulation of pathogenicity } \\
\text { factors }\end{array}$ & core genome & [86] \\
\hline xanthan biosynthesis ${ }^{\mid P D}$ & core genome & [87] \\
\hline $\begin{array}{l}\text { lipopolysaccharide } \\
\text { biosynthesis }\end{array}$ & core genome & [54] \\
\hline
\end{tabular}

a The $X$ tg core genome comprises orthologous CDS shared by five Swiss strains, i.e. Xtg2, Xtg9, Xtg10, Xtg29, and CFBP 2053 as well as NCPPB 3709 and ICMP 6431 isolated in Norway and New Zealand, respectively. Asterisks (*) indicate strains whose genomes revealed a reduced number of homologues in comparison to the type $\mathrm{VI}$ secretion system gene cluster identified for Xtg2 (Additional file 5: Table S3)

IPD Slight intra-pathovar differences (IPD) of gene clusters conserved among the seven Xtg strains were observed for the one encoding for xanthan biosynthesis (gene fusion of gumK and gumL in the genome of NCBBP 3709) and the gene cluster of LPS biosynthesis (gene separation events due to nonsense mutations in two individual genes among different Xtg strains) region, while the $\mathrm{C}$-terminus was found to be largely conserved (Fig. 7a).

High sequence deviations were further found for pilins of the type IV pilus (T4P). Comparison of the different non-graminis $X$. translucens strains with the corresponding T4P genes in Xtg29, revealed two groups of genes, differing in conservation (Fig. 6). In total, 15 out of 22 genes were highly conserved with more than $94.49 \%$ sequence identity. In contrast, in the second group of T4P genes, significantly lower values were observed for the major pilin PilA (44.85-75.56\%) and the minor pilins PilE, PilX, PilW, PilV, and FimT (35.98-52.41\%). Additionally, we found the putative tip-associated adhesin PilY1 to share only 27.97 to $30.57 \%$ AA sequence identity with Xtg29. Similar to HrpE, also the major T4P pilin PilA revealed further distinct differences between the other $X$. translucens pathovars. Highest sequence similarity was observed for Xtu4699 and DAR61454 (99.34\%) as well as LMG 728 and LMG 730 (97.3\%), followed by $75.56 \%$ AA identity for the PilA homologues of LMG 727 and Xtg29. Otherwise, only low sequence similarity (40.85-64.58\% AA identity) was found among the $X$. translucens pathovars. However, in contrast to HrpE, the PilA homologues were characterized by a highly conserved $\mathrm{N}$-terminus of at least 28 AA, while the $\mathrm{C}$-terminal region revealed extensive sequence deviations (Fig. 7b).

Analysis of the minor pilins (i.e. PilE, PilX, PilW, PilV, and FimT) and the putative tip-associated adhesin PilY1 revealed differing similarity patterns. Thus, $X . t$. pv. graminis $\mathrm{Xtg} 29$ and $X . t$. pv. poae LMG 728 revealed only 27.97 to 56.42 AA identity with any other $X$. translucens pathovar (Additional file 7: Figure S3), while those, in contrast, shared more than $74.55 \%$ AA sequence identity among each other. Among the seven Xtg strains, all pilins of the T4P and T3SS were highly conserved (AA identities $>99 \%$ ). 


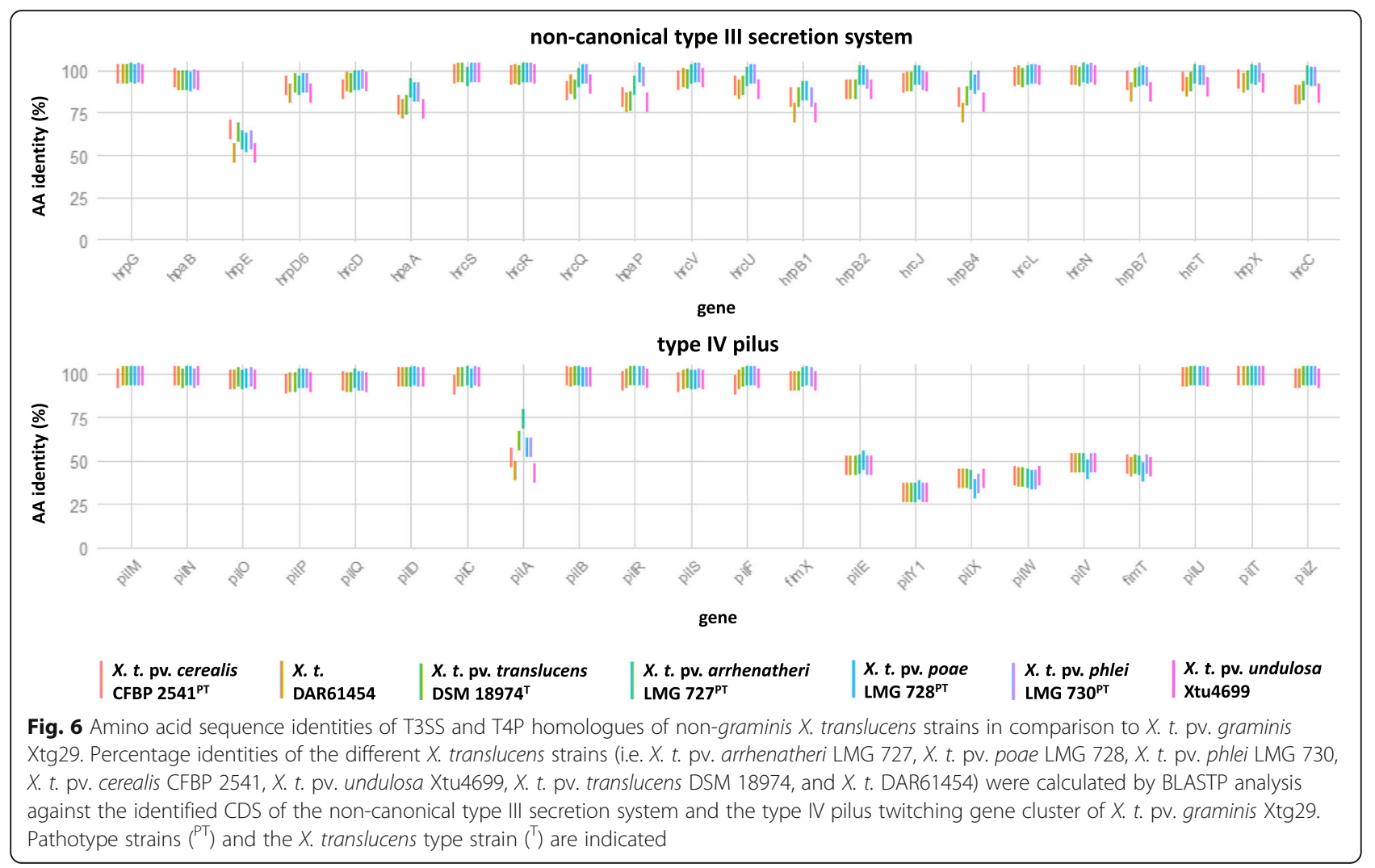

Comparison of the graminis group pathovars further revealed inter-pathovar differences of the $w x c$ gene cluster of LPS O-antigen biosynthesis. These were manifested in a variable, central part of seven to nine genes, flanked by highly conserved regions of seven and six genes, respectively (Additional file 8, Figure S4). The variable gene cluster section was only found to differ between the pathovars graminis, arrhenatheri, poae, and phlei, but did not show intra-pathovar differences among the seven $X \operatorname{tg}$ strains.

\section{A set of 74 CDS was specific to the $X t g$ core genome and revealed various pathogenicity-related functions}

For comparison of the Xtg core genome with the nongraminis $X$. translucens strains, a set of 74 CDS was predicted as true singletons of the pv. graminis. Among those, 42 CDS encoded for hypothetical proteins including eight with signal peptide motifs (Additional file 9: Table S5). Additional two CDS showed homology to IS elements (i.e., one transposase and one integrase). The remaining 30 CDS were functionally annotated based on sequence similarity and conserved protein domains (Table 5). According to their predicted functions, 28 of those genes were assigned to four categories, i.e. nutrient acquisition, regulation \& modification, virulence as well as adhesion \& motility. Additionally, two genes encoding for an invertase and a putative ABC-type ATPase were grouped as genes of other functions. With ten representative genes, the group of nutrient acquisition formed one of the largest groups among the predicted singletons and was characterized by the prediction of seven secretion signals for SEC-dependent translocation across the cytoplasmic membrane. Members of the 'nutrient acquisition group' comprised two glycerophosphodiester phosphodiesterases as well as a TonB-dependent receptor and various transporters. Also the category 'regulation \& modification' comprised ten CDS. Those largely encoded for restriction/modification systems as well as toxin-antitoxin components. Furthermore, we identified one transcriptional regulator of the XRE family as well as a peptidyl-prolyl cis-trans isomerase, further characterized by a predicted signal peptide. Four putative effector proteins were grouped into the category of virulence. Among those, only two (i.e. XTGART29_1903 and XTGART29_2268) revealed high sequence similarity (E-value $<10^{-50}$ ) to other Xanthomonas species. The remaining two stood out by their sequence identity to Pseudomonas spp., while also XTGART29_1903 possessed high sequence similarity to Ralstonia solanacearum. In total, three effector proteins were predicted to harbor an upstream plant-inducible-promoter (PIP) box. Another four CDS grouped in the category of 


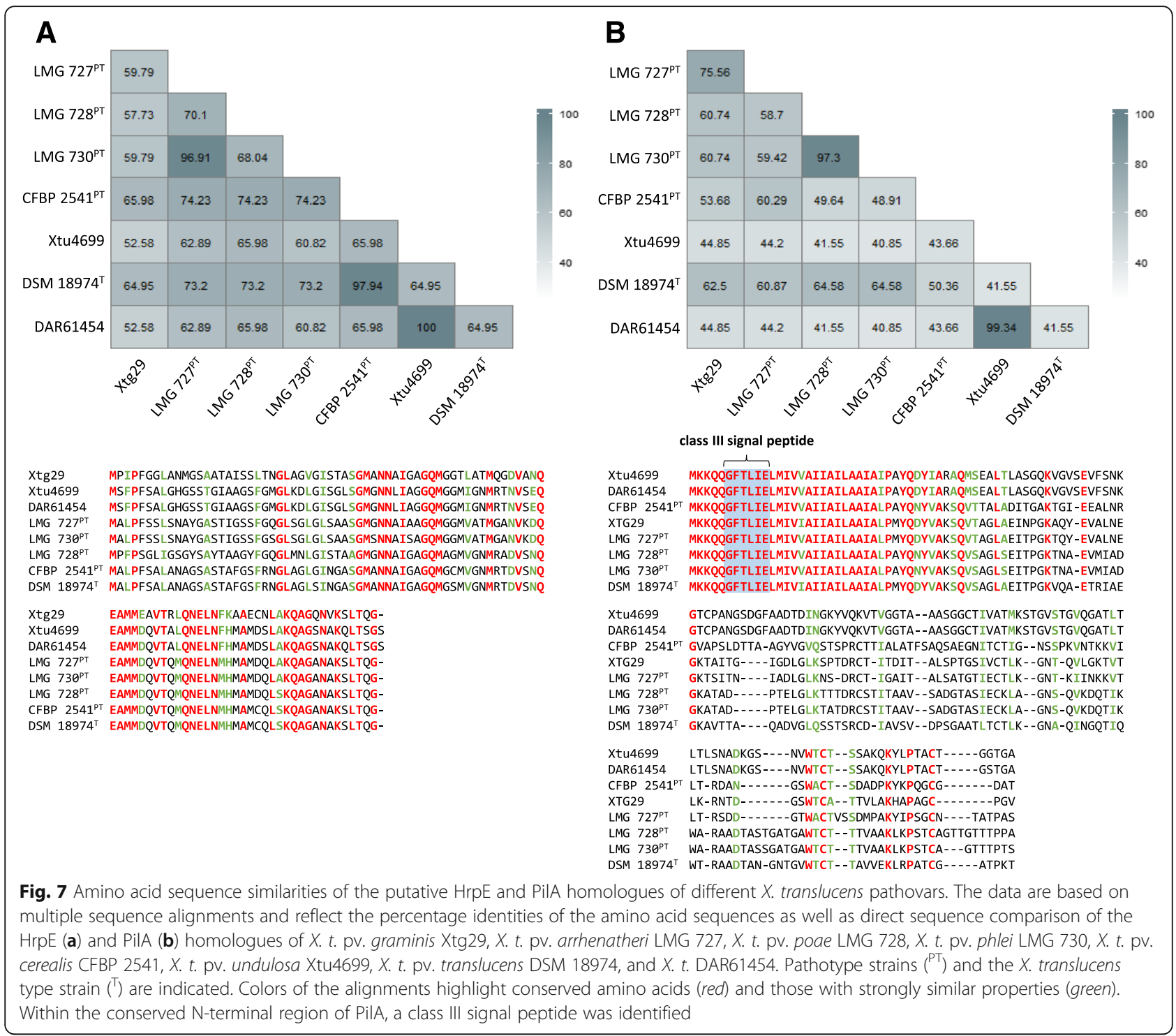

adhesin and motility. Two neighboring CDS, which were separated by a sequence gap in the assembly data, exhibited sequence similarity to different parts of filamentous hemagglutinin. Specific gap closure of this sequence using Sanger sequencing revealed the presence of a transposase between the two CDS. Most striking was the prediction of the putative T4P adhesin PilY1 and the minor pilin PilX as singletons of $X t g$, while corresponding homologues were also identified in the other pathovars. Closer manual inspection of these findings revealed that distinct PilY1 and PilX homologues with similarities of $30-40 \%$ exist for the corresponding CDS in the other pathovars. These, however, were discarded in the EDGAR-based similarity analysis due to the strict orthology cutoff as employed in the EDGAR framework.

\section{Discussion}

Comparative genome analysis was applied to unravel virulence-contributing traits of Xanthomonas translucens pv. graminis $(X t g)$ with a link to its pathogenicity on Italian ryegrass. Our results clearly demonstrate that the Xtg strains form a genetically distinct group characterized by a large conserved core genome. Comparison to other $X$. translucens pathovars allowed the identification of pathovar graminis-specific genomic traits involved in regulatory mechanisms and nutrient acquisition. Furthermore, distinct amino acid sequences of putative pathogenassociated molecular patterns (PAMPs), such as pilins of the non-canonical type III secretion system and the type IV pilus were found to distinguish Xtg strains from other $X$. translucens pathovars and might influence host adaptation of the pv. graminis. 
Table 5 True singletons of the X. t. pv. graminis core genome identified in comparison with non-graminis X. translucens strains

\begin{tabular}{|c|c|c|c|c|c|}
\hline Category $^{a}$ & Gene $^{b}$ & Description & Domain $^{c}$ & Feature $^{d}$ & Homology ${ }^{\mathrm{e}}$ \\
\hline NA & 0088 & glycerophosphodiester phosphodiesterase & cd08566 & $S$ & $\mathrm{X}, \mathrm{O}$ \\
\hline NA & 0362 & putative phosphate $A B C$ transporter & $\mathrm{cl} 21456$ & $\mathrm{~S}$ & $\mathrm{X}, \mathrm{O}$ \\
\hline NA & 0369 & biopolymer transporter ExbD & COG0848 & & \\
\hline NA & 0370 & biopolymer transporter ExbB & COG0811 & $S$ & $\mathrm{X}, \mathrm{O}$ \\
\hline NA & 0371 & hemolysin activator protein & COG2831 & & $\mathrm{X}, \mathrm{O}$ \\
\hline NA & 0436 & TonB-dependent receptor & TIGR01782 & $S$ & $\mathrm{x}, \mathrm{O}$ \\
\hline NA & 0438 & putative MFS/sugar transport protein & pfam13347 & & $\mathrm{X}, \mathrm{O}$ \\
\hline NA & 0441 & putative glycerophosphodiester phosphodiesterase & cd08566 & $S$ & \\
\hline NA & 1321 & MFS transporter & pfam07690 & & \\
\hline NA & 2335 & alpha-galactosidase & cd14792 & S & $\mathrm{X}, \mathrm{O}$ \\
\hline $\mathrm{Vl}$ & 0478 & putative type III effector protein, XopE class & - & PIP & $\mathrm{O}$ \\
\hline $\mathrm{Vl}$ & 0894 & putative cysteine protease, YopT-like & cl04145 & & O \\
\hline $\mathrm{VI}$ & 1903 & putative type III effector protein, XopJ class & cl07849 & PIP & $\mathrm{X}, \mathrm{O}$ \\
\hline $\mathrm{Vl}$ & 2268 & putative type III effector protein & - & PIP & $\mathrm{X}, \mathrm{O}$ \\
\hline RM & 0087 & peptidylprolyl isomerase & pfam00639 & $S$ & $x$ \\
\hline RM & 0480 & XRE family transcriptional regulator & COG1396 & & $\mathrm{X}, \mathrm{O}$ \\
\hline RM & 1782 & putative toxin-antitoxin system toxin component, VapC/FitB-like & cd09861 & & \\
\hline RM & 1783 & putative toxin-antitoxin system antitoxin component, SpoVT/AbrB-like & smart00966 & & \\
\hline RM & 2588 & type I restriction and modification protein subunit $\mathrm{M}$ & TIGR00497 & & $\mathrm{X}, \mathrm{O}$ \\
\hline RM & 2592 & putative type I restriction and modification protein subunit $S$ & COG0732 & & O \\
\hline RM & 2593 & type I restriction and modification protein subunit $\mathrm{R}$ & COG0610 & & $\mathrm{X}, \mathrm{O}$ \\
\hline RM & 2620 & toxin-antitoxin system toxin component, RelE/ParE family & COG3668 & & \\
\hline RM & 2990 & site-specific DNA-methyltransferase & COG0863 & & O \\
\hline RM & 3368 & C-5 cytosine-specific DNA methylase & COG0270 & & $\mathrm{x}, \mathrm{O}$ \\
\hline AM & 0364 & filamentous hemagglutinin, partial & - & & $\mathrm{X}, \mathrm{O}$ \\
\hline AM & 0365 & filamentous hemagglutinin, partial & smart00912 & S & $\mathrm{X}, \mathrm{O}$ \\
\hline AM & 2129 & type IV pilus assembly protein, tip-associated adhesin PilY1 & COG3419 & & $\mathrm{X}, \mathrm{O}$ \\
\hline AM & 2130 & type IV pilus assembly protein PilX & COG4726 & & \\
\hline OF & 1784 & invertase & cd03768 & & $\mathrm{X}, \mathrm{O}$ \\
\hline OF & 2590 & putative ABC-type ATPase & Cl21455 & & \\
\hline
\end{tabular}

a Abbreviations: NA nutrient acquisition, $V I$ virulence, $R M$ regulation and modification, $A M$ adhesion and motility, OF other function

b 4-digit number corresponding to the gene ID with the prefix XTGART29_. Listed genes were identified as true singletons of the Xtg core genome when compared against X. t. pv. arrhenatheri LMG 727, X. t. pv. poae LMG 728, X. t. pv. phlei LMG 730, X. t. pv. cerealis CFBP 2541, X. t. pv. undulosa Xtu4699, X. t. pv. translucens DSM 18974 and $X$. t. DAR61454

${ }^{c}$ Conserved domains (E-value $<10^{-06}$ )

${ }^{d}$ Features describing the presence of an upstream PIP-box (PIP) or a signal peptide (S)

e Homology to at least one other Xanthomonas species $(X)$ or another bacterial genus $\left(\mathrm{O}\right.$; E-value $<10^{-50}$ )

$X$ tg strains represent a genetically distinct $X$. translucens pathovar

The close genetic relation of Xtg strains is reflected by a large core genome and a phylogenetic clustering distinct from the other $X$. translucens pathovars. Interestingly, we also found that all seven Xtg strains possessed only small numbers of strain-specific singletons, although the pathotype strain CFBP 2053 genome revealed roughly 300 additional CDS in comparison to the genome data of $X \mathrm{tg}$ strains sequenced in this study. However, our data showed that only the singletons of CFBP
2053 comprised transposases, for which several identical paralogues were predicted across the genome. Genomic regions with transposase genes are generally difficult to assemble, because they often occur in identical copies across the genome [45]. In contrast to the $X \operatorname{tg}$ strains sequenced in this study, the SOAP GapCloser [46] has been used to close gaps in the genome assembly of CFBP 2053 [47]. This may explain at a technical level the observations of transposase genes in CFBP 2053, where they represent the main cause for the higher number of predicted CDS. 


\section{Swimming-deficiency is a common characteristic of Xtg strains}

The absence of a flagellar gene cluster as found for the majority of Xtg strains analyzed in this study as well as the observed swimming-deficiency on soft agar confirmed the formerly reported non-motility of the pathovar graminis [48] (Fig. 4). Yet, the presence of a nearly complete flagellar gene cluster in the swimmingdeficient Xtg strain NCPPB 3709 suggests that also motile pv. graminis strains may exist. Although, to the best of our knowledge, none has been described so far. The flagellum has been reported to primarily function in epiphytic biofilm formation and to enable the bacteria to move towards suitable entry points [49]. As Xtg is primarily transmitted by contaminated mowing tools [50], flagellar motility seems not essential for the pathogen's lifestyle. The same transmission strategies are likely to be valid among all forage grass affecting $X$. translucens pathovars, such as pv. arrhenatheri, pv. poae, and pv. phlei, of which all pathotype strains, however, were found to be capable of swimming. Aside from mediating bacterial motility, the flagellum features one of the most prevalent and best studied pathogen-associated molecular patterns (PAMP), i.e. the flagellin peptide flg22, which is an important elicitor of plant defense response [8]. Therefore, absence of the flagellar locomotion machinery might favor Xtg's ability to cause bacterial wilt on a wide host range by avoiding the elicitation of plant defense by flagellin.

\section{The T6SS is not a prevalent virulence factor of the pv. graminis}

In contrast to the other Xtg strains, Xtg2 was found to harbor all 13 homologues of a type VI secretion system (T6SS), recently described to represent the T6SS core genes [51]. When compared to T6SS gene clusters identified in other Xanthomonas spp., the one identified in Xtg2 revealed highest sequence similarity to a cluster recently described to be specific to cereal affecting xanthomonads such as X. translucens DAR61454 [18]. Due to the secretion of effector proteins and toxins, the T6SS was found to contribute to virulence and bacterial competition of bacterial pathogens [52]. However, high virulence on Italian ryegrass was also observed for Xtg strains lacking the T6SS, indicating that it may be neither an essential nor a prevalent virulence factor of the pv. graminis.

Intra-pathovar differences in virulence on Italian ryegrass are likely to come from strain-specific characteristics

Testing of the different Xtg strains for their pathogenicity on Italian ryegrass (Lolium multiflorum) revealed significant differences between the highly virulent Swiss strains and those isolated in Norway (NCPPB 3709) and
New Zealand (ICMP 6431; Fig. 3). Both, NCPPB 3709 and ICMP 6431 were isolated from $L$. perenne, while the Swiss strains originated from L. multiflorum (Table 1). Thus, it is tempting to speculate that differences in virulence might be dependent on different host adaptation. Previous studies on Xtg strains, however, revealed no differences in virulence due to varying host plants or different geographical origin [4]. Furthermore, we did not find any CDS to be shared within, but not among the two groups and suppose differences in strain-specific traits to be causative for the observed variations. These may be related to certain genes and/or single nucleotide polymorphisms (SNPs) in coding sequences or regulatory elements. For the Norwegian Xtg strain NCPPB 3709 for instance, we observed a nonsense mutation in the xanthan biosynthesis gene cluster, which resulted in the fusion of $g u m K$ and gumL. It has been found for X. oryzae that mutation of $g u m K$ has resulted in a reduction of both, xanthan production and lesion length in a susceptible rice cultivar [53]. Thus, the gene fusion in the gene cluster of NCPPB 3709 may affect production of the extracellular polysaccharide xanthan and its pathogenicity on Italian ryegrass. However, in accordance with a recent finding for $X . t$. pv. arrhenatheri LMG 727, where a fusion of gumK and gumL was also observed [16], the mucoid appearance of NCPPB 3709 showed no differences in comparison to the other $X$. translucens strains.

\section{Differences in the LPS O-antigen encoding wxc gene cluster differentiate $X t g$ from other graminis-group pathovars}

Lipopolysaccharides (LPS) are the main component of the bacterial cell envelope of Gram-negative bacteria and are well-known elicitors of plant defense reactions such as the release of reactive oxygen species and accumulation of pathogenesis related proteins [9]. Analysis of the seven Xtg strains revealed slight intra-pathovar differences within the $w x c$ gene cluster, which is involved in the LPS O-antigen biosynthesis [54]. These may only cause minor differences on the LPS structure, as previous profiling revealed a homogeneous LPS pattern within the pv. graminis [55]. The study further reported the pv. graminis LPS profile to differ from the other $X$. translucens pathovars. Recent comparative genome analyses revealed inter-pathovar differences of the $w x c$ gene cluster for $X . t$. pv. arrhenatheri, X. t. pv. poae, and X. $t$. pv. phlei [16]. These differences derive from a region within the $w x c$ gene cluster consisting of seven to eight genes, which also revealed distinct differences to $X$. $t$. pv. graminis. Among the investigated Xtg strains, however, the corresponding region was well conserved (Additional file 8: Figure S4). Mutational analysis of the $w x c$ gene cluster in $X$. campestris pv. campestris led to the differentiation of three regions, involved in the LPS O-antigen biosynthesis, the formation of the LPS core as well as 
the translocation and modification of sugar composition [54]. Thus, differences in the $w x c$ gene cluster observed for the Xtg strains and among the X. translucens pathovars may affect different structural components. Hypervariability of the LPS gene cluster is common among Xanthomonas spp., but revealed no apparent correlation with host specificity [56]. Nevertheless, intra-species differences as observed for $X$. translucens might result in pathovar-specific LPS structures, which so far have not been experimentally resolved.

Xtg strains possess distinct primary structures for pilins of the T4P and T3SS

As described for other plant pathogenic bacteria, in planta colonization by Xtg is likely to be dependent on the type IV pilus (T4P), which mediates adherence and twitching motility [57]. A corresponding gene cluster was also identified in the other $X$. translucens pathovars. While most of the homologues were well conserved, we observed highly divergent primary structures for the T4P pilin subunits PilA, PilE, PilX, PilV, PilW and FimT of $X$. t. pv. graminis (Fig. 6). With respect to the direct contact with the host organism, it seems likely that the T4P pilus subunits may be elicitors of plant defense. Sequence variations as observed for the $X$. translucens pathovars may therefore facilitate their ability to cause bacterial wilt in certain host plants by evading recognition through the plant defense machinery [58]. As recently reviewed by Dunger et al. [59], the T4P plays an important role in pathogenesis of various Xanthomonas species. The contribution of the type IV pilus for bacterial wilt in forage grasses has not been addressed so far, but the largely conserved gene cluster indicates that it may assist plant colonization. If that is the case, especially the high sequence variability of the pilin subunits and its putative role in host adaptation are worth deeper analysis.

Also, the type III secretion system represents an extracellular structure, which mediates direct contact to the host organism [60]. Comparison of different X. translucens pathovars revealed a largely conserved gene cluster of the non-canonical type III secretion system as previously described for Xtg29 [12]. The pilus subunit HrpE, in contrast, displayed strong sequence heterogeneity. The sequence deviations mainly occurred in the $\mathrm{N}$ terminal sequence, while the C-terminus was largely conserved among the $X$. translucens pathovars (Fig. 7). Similar findings were previously reported for comparative analysis of HrpE homologues in other Xanthomonas species $[60,61]$. The authors proposed the highly variable $\mathrm{N}$-terminus as the surface exposed region, while the $\mathrm{C}$-terminus most likely encodes for the polymerization domain of HrpE. The C-terminal region of $X$. translucens HrpE homologues revealed only low amino acid identity to the investigated xanthomonads (Additional file 10: Figure S5). However, hydrophobicity plot analysis by using the Kyte and Doolittle hydrophobicity scale [62] revealed a similar pattern as observed for the other Hrp pilins and therefore suggests a similar folding [63] (data not shown). Moreover, it has been reported, that the knock-out of $h r p E$ in Xtg29 resulted in a drastically reduced virulence on Italian ryegrass as also observed for mutants of the regulator HrpG and the structural component HrcR [12]. With respect to these findings, we assume HrpE as a functional subunit for type III secretion and the observed differences in percentage sequence identity as pathovar-specific traits.

\section{Xtg-specific CDS are characterized by effector proteins, transporters, regulatory systems and a large number of hypothetical proteins}

More than half of the 74 CDS predicted to be specific to $X$. translucens pv. graminis, were predicted as hypothetical proteins. Among those, 18 were found to be conserved in other bacteria and therefore suggest that they may be essential for bacterial fitness [64]. Moreover, eight were predicted to possess a signal peptide, which indicates that they are involved in the interaction with the environment [65]. Several studies revealed a reduced or even complete loss of virulence for hypothetical proteins affected by transposon-insertion mutagenesis in Xanthomonas spp. [66, 67]. Thus, along with the functionally annotated CDS, the identified hypothetical proteins need to be considered as crucial pathogenicity-associated traits of X. $t$. pv. graminis.

Among the functional annotated CDS, four type III effector proteins were predicted to be specific to the pv. graminis core genome. Three of those revealed a plantinducible promoter (PIP) sequence, which indicates that they are regulated in HrpX-dependent manner as part of the HrpX regulon [68]. Moreover, the effector proteins were largely found to reveal high sequence similarity to other bacterial genera such as Pseudomonas and Ralstonia, which might indicate their acquisition by horizontal gene transfer [69]. This assumption is further supported by the low GC values of 53.24 to $60.22 \%$, which deviate considerably from the Xtg average of $69 \%$ (Additional file 1: Table S1). Moreover, we found both, an integrase and a transposase downstream of XTGART29_1903. These genes were also predicted as true singletons of the Xtg core genome. With view on the host range determining function of effector proteins [70], it is likely that the four effector proteins contribute to the virulence of $X t g$.

Among the other $X t g$-specific CDS, nine signal peptides were predicted. These are likely to be targeted to the Sec system, which mediates the translocation over the inner membrane into the periplasm and is in some cases linked to a second translocation step into the extracellular milieu via the type II secretion system 
(T2SS) [71]. Effectively, we identified various transporters along with a TonB-dependent receptor, which are embedded in the bacterial cell wall and mediate the uptake of phosphate, iron-siderophore complexes, vitamin B12 and carbohydrates [72]. The importance of such transporter systems for successful host colonization has been demonstrated by a transposon insertion mutagenesis study, which revealed a reduction of both, the in planta multiplication and the virulence of $X$. albilineans [67].

With view on the pathogen's lifestyle beyond plant invasion, i.e. epiphytic and/or saprophytic growth, the transcriptional regulation of virulence factors is crucial for energy conservation, evasion of host defense and disease development [73]. Recent transcriptome analysis revealed differential gene expression of T2SS substrates not only in dependence of the cultivation media but also between the two X. citri pv. citri strains XccA306 and Xcaw12879, which are characterized by broad host range and high host specificity, respectively [74]. Thus, it is possible that regulatory mechanisms play a central role for host adaptation processes of $X . t$. pv. graminis. Genes involved in 'regulation and modification' formed the second largest group of functional annotated singletons of the pv. graminis and largely comprised components of restriction-modification and toxin-antitoxin complexes. Restriction-modification systems are mainly known for their protective function against foreign DNA from phages [75]. Both, the DNA methyltransferase (modification domain) and the restriction enzyme (restriction domain) recognize the same target sequence and solely DNA lacking the modification imprint are degraded by the endonuclease. The type I restriction system identified within the $X t g$ singletons is a multifunctional enzyme consisting of three different domains, which are important for the methylation and restriction function [75]. The two orphan methyltransferases (MTases), in contrast, did not reveal a neighboring restriction enzyme and are most likely involved in epigenetic regulation [76]. Among others, DNA MTases were shown to affect motility, adherence, and virulence [77] and thus represent promising regulators of virulence mechanisms in $X$. t. pv. graminis.

Toxin-antitoxin systems are also part of the bacterial epigenetic regulation [78]. Co-transcription and cotranslation of the stable toxin and degradation-prone antitoxin secures ordered segregation of replicons prior to cell division and plasmid maintenance due to postsegregationally killing [79]. The toxin-antitoxin (TA) system identified within the $X t g$ singletons revealed similarity to TA system recently described to be a common characteristic of various xanthomonads [80]. Additionally, a ParE-like toxin was found to be specific to the Xtg core genome. The corresponding antitoxin component, which was also conserved among the Xtg strains, revealed a homologue in the genome of X.t. pv. cerealis CFBP 2541 and was therefore not predicted as singleton. With view on the recently demonstrated virulence and avirulence function of the type III secreted effector and TA toxin AvrRxoI in Xanthomonas spp. [81], it would be interesting to elucidate the functional role of the identified TA system components in the Xtg - L. multiflorum interaction.

\section{Conclusion}

Our study substantially increased the available Xtg genome data by making results from additional strains available. This data was utilized for comparative genomics that also considered previously supplied genomes of the species $X$. translucens. In combination with a phenotypic characterization of key features, we identified genomic loci related to effector proteins, regulatory mechanisms, and nutrient acquisition as putative virulence contributing characteristics that distinguish $\mathrm{Xtg}$ from non-graminis X. translucens strains. Host adaptation of Xtg might be facilitated by the identified, unique primary structures conceivably involved in evasion of the plant perception machinery. These genomic traits represent promising candidates for new functional research with the ultimate aim to better understand fundamental principles of bacterial host adaptation and facilitate targeted breeding of new forage grass cultivars for bacterial wilt resistance.

\section{Additional files}

Additional file 1: Table S1. Sequencing data of Xtg strains. The results were obtained by sequencing of single paired-end libraries only (i.e. Xtg2, Xtg9, Xtg10, NCPPB 3709, and ICMP 6431) or in combination with a mate-pair library (i.e. Xtg29) by the Illumina MiSeq System. (DOCX 16 kb)

Additional file 2: Table S2. Xtg29 genome statistics based on data of the 454 Titanium FLX System and the Illumina MiSeq System sequencing strategies. (DOCX $15 \mathrm{~kb}$ )

Additional file 3: Figure S1. Number of CDS shared by and unique to $X$. t. pv. graminis of different geographic origin. The two Venn diagrams represent the comparison of either the core genome of the Swiss strains, i.e. Xtg29, Xtg2, Xtg9, and Xtg10 (A) or the Norwegian (NCPPB 3709) and New Zealand (ICMP 6431) strain (B) against the other Xtg strains. (PDF 299 kb)

Additional file 4: Figure S2. Number of strain-specific CDS predicted for seven Xtg strains. The data reflect the amount of predicted hypothetical proteins (blue), CDS with annotated functions (green) as well as detected transposases (grey). (PDF $171 \mathrm{~kb}$ )

Additional file 5: Table S3. Type VI secretion system homologues identified in Xtg2 and their corresponding COG numbers (E-value $<10$ ${ }^{-20}$ ). Except of two CDS (i.e. XTGART2_1599 and XTGART2_1602), homologues were also identified in the genomes of Xtg9, $X \operatorname{tg} 10$, and NCPPB 3709. (DOCX $15 \mathrm{~kb})$

Additional file 6: Table S4. Type IV pilus homologues identified for Xtg29 and their corresponding COG numbers (E-value $<10^{-12}$ ). (DOCX $17 \mathrm{~kb}$ )

Additional file 7: Figure S3. Percentage identity matrix of the minor type IV pilus pilins PilE, PilX, PilW, PilV, and FimT as well as the T4P adhesin PilY1 across $X$. translucens strains (i.e. X. t. pv. graminis Xtg29, X. t. pv. arrhenatheri LMG 727, X. t. pv. poae LMG 728, X. t. pv. phlei LMG 730, X. t. pv. cerealis CFBP 2541, X. t. pv undulosa Xtu4699, X. t. pv. translucens DSM 18974, and X.t. DAR61454) including pathotype strains ( $\left.{ }^{\mathrm{PT}}\right)$ and the 
$X$. translucens type strain ( ${ }^{\top}$ ). Class III signal peptides identified for the minor pilins are indicated. For PilW homologues in X.t. pv. translucens DSM 18974 and X. t. DAR61454 no corresponding class III signal peptide was found. (PDF $386 \mathrm{~kb}$ )

Additional file 8: Figure S4. $w \times x$ gene cluster comparison of four $X$. translucens pathovars represented by $X . t$. pv. graminis Xtg 2 and the pathotype strains $X$. t. pv. arrhenatheri LMG $727^{\mathrm{PT}}$, X. t. pv. poae LMG $728^{\mathrm{PT}}$, and $X$. t. pv. phlei LMG $730^{\mathrm{PT}}$. The strain Xtg2 was chosen as a representative of the pv. graminis. Intra-pathovar differences of Xtg strains, i.e. CDS with gene separation events due to non-sense mutations as observed for Xtg29, ICMP 6431, and NCPPB 3709, are indicated by red borders. Inter-pathovar gene cluster comparison revealed a highly variable region highlighted by a grey background, while the flanking regions were largely conserved. (PDF 202 kb)

Additional file 9: Table S5. Xtg core singleton CDS which encode hypothetical proteins or IS elements. (DOCX $17 \mathrm{~kb}$ )

Additional file 10: Figure S5. Multiple sequence alignment of HrpE homologues of Xanthomonas spp. including seven Xanthomonas translucens pathovars. (PDF $51 \mathrm{~kb}$ )

Additional file 11: Figure S6. Topology of the phylogenetic tree of $X$. translucens pathovars including percent conservation values in 500 bootstrapping iterations. (PDF $343 \mathrm{~kb}$ )

\section{Abbreviations}

COG: Clusters of orthologous groups; CTAB: Cetyltrimethylammonium bromide; IS: Insertion; Rpf: Regulation of pathogenicity factors; Xps: Xanthomonas protein secretion

\section{Acknowledgements}

The authors thank Anika Winkler for her assistance in genome sequencing and gratefully acknowledge the financial support of the EDGAR platform by the BMBF grant FKZ 031 A533 within the de.NBI network.

\section{Funding}

This project was funded by the Swiss National Science Foundation as part of the project "Bacterial wilt in ryegrass: targeted characterization of virulence factors and resistance genes" (Grant number: 138358).

\section{Availability of data and materials}

Sequence data of Xtg strains is available at the GenBank database under the following accession numbers: PRJEB10857 (Xtg29); PRJEB10858 (Xtg2); PRJEB10859 (Xtg9); PRJEB10860 (Xtg10); PRJEB10861 (ICMP 6431); PRJEB10862 (NCPPB 3709).

\section{Authors' contributions}

$\mathrm{LH}$ and RK designed the study and drafted the manuscript. LH wrote the manuscript, assisted by RK, DW, JB, FJV, FW and AG. FJV coordinated genome sequencing and $A G$ provided bioinformatics infrastructure. DW and JB performed genome assembly and genome annotation, respectively. LH conducted the genomic DNA extraction, the pathogenicity assay and the motility assay as well as data analysis supported by DW and JB. All authors read and approved the final version of the manuscript.

\section{Competing interests}

The authors declare that they have no competing interests.

\section{Consent for publication}

Not applicable.

\section{Ethics approval and consent to participate}

Not applicable.

\section{Author details}

${ }^{1}$ Molecular Ecology, Agroscope, 8046 Zurich, Switzerland. ${ }^{2}$ Center for Biotechnology, Bielefeld University, 33615 Bielefeld, Germany. ${ }^{3}$ Bioinformatics and Systems Biology, Justus Liebig University Giessen, 35392 Giessen, Germany. ${ }^{4}$ MVZ Dr. Eberhard \& Partner Dortmund, 44137 Dortmund, Germany.
Received: 16 July 2016 Accepted: 14 December 2016

Published online: 05 January 2017

\section{References}

1. O'Mara FP. The role of grasslands in food security and climate change. Ann Bot. 2012;110(6):1263-70

2. Hayward AC. The hosts of Xanthomonas. In: Swings J, Civerolo EL, editors. Xanthomonas. London: Chapman \& Hall; 1993. p. 1-119.

3. Egli T, Goto M, Schmidt D. Bacterial wilt, a new forage grass disease. Phytopathol Z. 1975;82:111-21.

4. Egli T Schmidt D. Pathogenic variation among the causal agents of bacterial wilt of forage grasses. Phytopathol Z. 1982;104:138-50.

5. Schmidt D, Neusch B. Resistance to bacterial wilt (Xanthomonas graminis) increases yield and persistency of Lolium multiflorum. EPPO Bulletin. 1980; 10(3):335-9.

6. Boller B, Peter-Schmid MKI, Tresch E, Tanner P, Schubiger FX. Ecotypes of Italian ryegrass from Swiss permanent grassland outperform current recommended cultivars. Euphytica. 2009;170:53-65.

7. Michel W. Interactions between Xanthomonas campestris pv. graminis strains and meadow fescue and Italian rye grass cultivars. Plant Dis. 2001;85: 538-42.

8. Zipfel C, Robatzek S, Navarro L, Oakeley EJ, Jones JDG, Felix G, Boller T. Bacterial disease resistance in Arabidopsis through flagellin perception. Nature. 2004:428:764-7.

9. Erbs G, Newman MA. The role of lipopolysaccharide and peptidoglycan, two glycosylated bacterial microbe-associated molecular patterns (MAMPs), in plant innate immunity. Mol Plant Pathol. 2012;13(1):95-104.

10. Kay S, Bonas U. How Xanthomonas type III effectors manipulate the host plant. Curr Opin Microbiol. 2009;12:37-43.

11. Büttner D, Noël L, Stuttmann J, Bonas U. Characterization of the nonconserved hpaB-hrpF region in the hrp pathogenicity island from Xanthomonas campestris pv. vesicatoria. MPMI. 2007;20(9):1063-74.

12. Wichmann F, Vorhölter FJ, Hersemann L, Widmer F, Blom J, Niehaus K, Reinhard S, Conradin C, Kölliker R. The noncanonical type III secretion system of Xanthomonas translucens pv. graminis is essential for forage grass infection. Mol Plant Pathol. 2013;14(6):576-88.

13. Finlay BB, Falkow S. Common themes in microbial pathogenicity revisited. Microbiol Mol Biol Rev. 1997;61 (2):136-69.

14. Pesce C, Bolot S, Cunnac S, Portier P, Fischer-Le Saux M, Jacques MA, Gagnevin L, Arlat M, Noël LD, Carrère S, et al. High-quality draft genome sequence of the Xanthomonas translucens pv. cerealis pathotype strain CFBP 2541. Genome Announc. 2015;3(1):e01574-01514.

15. Peng Z, Hu Y, Xie J, Potnis N, Akhunova A, Jones J, Liu Z, White FF, Liu S. Long read and single molecule DNA sequencing simplifies genome assembly and TAL effector gene analysis of Xanthomonas translucens. BMC Genomics. 2016;17:21.

16. Hersemann L, Wibberg D, Widmer F, Vorhölter FJ, Kölliker R. Draft genome sequences of three Xanthomonas translucens pathovar reference strains (pv. arrhenatheri, pv. poae and pv. phlei) with different specificities for forage grasses. Stand Genomic Sci. 2016;11:50

17. Jaenicke S, Bunk B, Wibberg D, Spröer C, Hersemann L, Blom J, Winkler A, Schatschneider S, Albaum S, Kölliker R, et al. Complete genome sequence of the barley pathogen Xanthomonas translucens pv. translucens DSM 18974 ${ }^{\top}$ / ATCC 19319 ${ }^{\top}$ Genome Announc. 2016:4(6):e01334-16.

18. Gardiner DM, Upadhyaya NM, Stiller J, Ellis JG, Dodds PN, Kazan K, Manners JM. Genomic analysis of Xanthomonas translucens pathogenic on wheat and barley reveals cross-kingdom gene transfer events and diverse protein delivery systems. PLoS One. 2014;9(1):e84995.

19. Paul VH, Smith IM. Bacterial pathogens of Gramineae: systematic review and assessment of quarantine status for the EPPO region. Bull OEPP/EPPO Bull. 1989:19:33-42

20. Kölliker R, Kraehenbuehl R, Boller B, Widmer F. Genetic diversity and pathogenicity of the grass pathogen Xanthomonas translucens pv. graminis. Syst Appl Microbiol. 2006;29:109-19.

21. William S, Feil H, Copeland A. Bacterial genomic DNA isolation using CTAB In: Protocols Joint Genome Institute; 2012. http://jgi.doe.gov/collaboratewith-jgi/pmo-overview/protocols-sample-preparation-information/. Accessed 20 Dec 2016

22. Glenn TC. Field guide to next-generation DNA sequencers. Mol Ecol Resour. 2011;11:759-69. 
23. Benjamini Y, Speed TP. Summarizing and correcting the GC content bias in high-throughput sequencing. Nucleic Acids Res. 2012;40(10):e72.

24. Wibberg D, Andersson L, Tzelepis G, Rupp O, Blom J, Jelonek L, Pühler A, Fogelqvist J, Varrelmann $M$, Schlüter $A$, et al. Genome analysis of the sugar beet pathogen Rhizoctonia solani AG2-2IIIB revealed high numbers in secreted proteins and cell wall degrading enzymes. BMC Genomics. 2016; $17: 245$.

25. Linke B, Giegerich R, Goesmann A. Conveyor: a workflow engine for bioinformatic analyses. Bioinformatics. 2011;27(7):903-11.

26. Hyatt $D$, Chen GL, LoCascio PF, Land ML, Larimer FW, Hauser LJ. Prodigal: prokaryotic gene recognition and translation initiation site identification. BMC Bioinformatics. 2010;11:119.

27. Lagesen K, Hallin P, Rødland EA, Stærfeldt HH, Rognes T, Ussery DW. RNAmmer: consistent and rapid annotation of ribosomal RNA genes. Nucleic Acids Res. 2007;35(9):3100-8.

28. Laslett D, Canback B. ARAGORN, a program to detect tRNA genes and tmRNA genes in nucleotide sequences. Nucleic Acids Res. 2004;32(1):11-6.

29. Blom J, Kreis J, Spänig S, Juhre T, Bertelli C, Ernst C, Goesmann A. EDGAR 2 0 : an enhanced software platform for comparative gene content analyses. Nucleic Acids Res. 2016;44(W1):W22.

30. Boeckmann B, Bairoch A, Apweiler R, Blatter MC, Estreicher A, Gasteiger E, Martin MJ, Michoud K, O'Donovan C, Phan I, et al. The SWISS-PROT protein knowledgebase and its supplement TrEMBL in 2003. Nucleic Acids Res. 2003;31(1):365-70

31. Finn RD, Bateman A, Clements J, Coggill P, Eberhardt RY, Eddy SR, Heger A, Hetherington K, Holm L, Mistry J, et al. Pfam: the protein families database. Nucleic Acids Res. 2014;42(D1):D222.

32. Pruitt KD, Tatusova T, Maglott DR. NCBI reference sequences (RefSeq): a curated non-redundant sequence database of genomes, transcripts and proteins. Nucleic Acids Res. 2007;35:D1-D65.

33. Vauterin L, Yang B, Hoste B, Pot B, Swings J, Kersters K. Taxonomy of xanthomonads from cereals and grasses based on SDS-PAGE of proteins, fatty acid analysis and DNA hybridization. J Gen Microbiol. 1992;138:1467-77.

34. Blom J, Albaum SP, Doppmeier D, Pühler A, Vorhölter FJ, Zakrzewski M, Goesmann A. EDGAR: A software framework for the comparative analysis of prokaryotic genomes. BMC Bioinformatics. 2009;10:154.

35. Edgar RC. MUSCLE: multiple sequence alignment with high accuracy and high throughput. Nucleic Acids Res. 2004;32(5):1792-7.

36. Felsenstein J. PHYLIP-phylogeny inference package (version 3.2). Cladistics. 1989:5:163-6.

37. Konstantinidis KT, Tiedje JM. Genomic insights that advance the species definition for prokaryotes. PNAS. 2005;102(7):2567-72.

38. Altschul SF, Gish W, Miller W, Myers EW, Lipman DJ. Basic local alignment search tool. J Mol Biol. 1990;215:403-10.

39. Marchler-Bauer A, Derbyshire MK, Gonzales NR, Lu S, Chitsaz F, Geer LY, Geer RC, He J, Gwadz M, Hurwitz DI, et al. CDD: NCBI's conserved domain database. Nucleic Acids Res. 2015;43(D1):D222.

40. Petersen TN, Brunak S, von Heijne G, Nielsen H. SignalP 4.0: discriminating signal peptides from transmembrane regions. Nat Methods. 2011;8(10):785-6.

41. Fenselau S, Bonas U. Sequence and expression analysis of the hrpB pathogenicity operon of Xanthomonas campestris pv. vesicatoria which encodes eight proteins with similarity to components of the Hrp, Ysc, Spa, and Fli secretion systems. MPMI. 1995;8(6):845-54.

42. Imam S, Chen Z, Roos DS, Pohlschroeder M. Identification of surprisingly diverse type IV pili, across a broad range of Gram-positive bacteria. PLoS One. 2011;6(12):e28919.

43. Wichmann F, Müller Hug B, Widmer F, Boller B, Studer B, Kölliker R. Phenotypic and molecular genetic characterization indicate no major racespecific interactions between Xanthomonas translucens pv. graminis and Lolium multiflorum. Plant Pathol. 2011;60(2):314-24.

44. $\mathrm{R}$ Core Team. Language and environment for statistical computing. $\mathrm{R}$ Foundation for Statistical Computing, Vienna, Austria; 2016

45. Siguier P, Filée J, Chandler M. Insertion sequences in prokaryotic genomes. Curr Opin Microbiol. 2006;9(5):526-31.

46. Luo R, Liu B, Xie Y, Li Z, Huang W, Yuan J, He G, Chen Y, Pan Q, Liu Y, et al. SOAPdenovo2: an empirically improved memory-efficient short-read de novo assembler. GigaScience. 2012;1:18.

47. Pesce C, Bolot S, Berthelot E, Bragard C, Cunnac S, Fischer-Le Saux M, Portier $P$, Arlat M, Gagnevin L, Jacques MA, et al. Draft genome sequence of Xanthomonas translucens pv. graminis pathotype strain CFBP 2053. Genome Announc. 2015;3(5):e01174-01115.
48. Van den Mooter M, Swings J. Numerical analysis of 295 phenotypic features of 266 Xanthomonas strains and related strains and an improved taxonomy of the genus. Int J Syst Bacteriol. 1990;40(4):348-69.

49. Tans-Kersten J, Huang $H$, Allen C. Ralstonia solanacearum needs motility for invasive virulence on tomato. J Bacteriol. 2001;183(12):3597-605.

50. Schmidt D. Epidemiological aspects of bacterial wilt of fodder grasses. Bull OEPP/EPPO Bull. 1989;19:89-95.

51. Boyer F, Fichant G, Berthod J, Vandenbrouck Y, Attree I. Dissecting the bacterial type VI secretion system by a genome wide in silico analysis: what can be learned from available microbial genomic resources? BMC Genomics. 2009;10:104.

52. Schwarz S, West TE, Boyer F, Chiang WC, Carl MA, Hood RD, Rohmer L, Tolker-Nielsen T, Skerrett SJ, Mougous JD. Burkholderia type VI secretion systems have distinct roles in eukaryotic and bacterial cell interactions. PLoS Pathog. 2010:6(8):e1001068.

53. Kim SY, Kim JG, Lee BM, Cho JY. Mutational analysis of the gum gene cluster required for xanthan biosynthesis in Xanthomonas oryzae pv oryzae. Biotechnol Lett. 2009;31:265-70.

54. Vorhölter FJ, Niehaus K, Pühler A. Lipopolysaccharide biosynthesis in Xanthomonas campestris pv. campestris: a cluster of 15 genes is involved in the biosynthesis of the LPS O-antigen and the LPS core. Mol Genet Genomics. 2001;266:79-95.

55. Ojanen T, Helander IM, Haahtela K, Korhonen TK, Laakso T. Outer membrane proteins and lipopolysaccharides in pathovars of Xanthomonas campestris. Appl Environ Microbiol. 1993;59(12):4143-51.

56. Lu H, Patil P, Van Sluys MA, White FF, Ryan RP, Dow JM, Rabinowicz P, Salzberg SL, Leach JE, Sonti R, et al. Acquisition and evolution of plant pathogenesis-associated gene clusters and candidate determinants of tissue-specificity in Xanthomonas. PLoS One. 2008;3(11):e3828.

57. Dunger G, Guzzo CR, Andrade MO, Jones JB, Farah CS. Xanthomonas citri subsp. citri type IV pilus is required for twitching motility, biofilm development, and adherence. Mol Plant-Microbe Interact. 2014;27(10):1132-47.

58. Craig L, Pique ME, Tainer JA. Type IV pilus structure and bacterial pathogenicity. Nat Rev Microbiol. 2004;2(5):363-78.

59. Dunger G, Llontop E, Guzzo CR, Farah CS. The Xanthomonas type IV pilus. Curr Opin Microbiol. 2016;30:88-97.

60. Weber E, Koebnik R. Positive selection of the Hrp pilin HrpE of the plant pathogen Xanthomonas. J Bacteriol. 2006;188(4):1405-10.

61. Weber E, Ojanen-Reuhs T, Huguet E, Hause G, Romantschuk M, Korhonen TK, Bonas U, Koebnik R. The type III-dependent Hrp pilus is required for productive interaction of Xanthomonas campestris pv. vesicatoria with pepper host plants. J Bacteriol. 2005;187(7):2458-68.

62. Kyte J, Doolittle RF. A simple method for displaying the hydropathic character of a protein. J Mol Biol. 1982;157(1):105-32.

63. Weber E, Koebnik R. Domain structure of HrpE, the Hrp pilus subunit of Xanthomonas campestris pv. vesicatoria. J Bacteriol. 2005;187(17):6175-86.

64. Jordan IK, Rogozin IB, Wolf YI, Koonin EV. Essential genes are more evolutionarily conserved than are nonessential genes in bacteria. Genome Res. 2002;12:962-8.

65. Desvaux M, Hébraud M, Talon R, Henderson IR. Secretion and subcellular localization of bacterial proteins: a semantic awareness issue. Trends Microbiol. 2009;17(4):139-45.

66. Qian W, Jia Y, Ren SX, He YQ, Feng JX, Lu LF, Sun Q, Ying G, Tang DJ, Tang $\mathrm{H}$, et al. Comparative and functional genomic analyses of the pathogenicity of phytopathogen Xanthomonas campestris pv. campestris. Genome Res. 2005; 15:757-67.

67. Rott P, Fleites L, Marlow G, Royer M, Gabriel DW. Identification of new candidate pathogenicity factors in the xylem-invading pathogen Xanthomonas albilineans by transposon mutagenesis. Mol Plant-Microbe Interact. 2011;24(5):594-605.

68. Koebnik R, Kruger A, Thieme F, Urban A, Bonas U. Specific binding of the Xanthomonas campestris pv. vesicatoria AraC-type transcriptional activator HrpX to plant-inducible promoter boxes. J Bacteriol. 2006;188(21):7652-60.

69. Juhas M, van der Meer JR, Gaillard M, Harding RM, Hood DW, Crook DW. Genomic islands: tools of bacterial horizontal gene transfer and evolution. FEMS Microbiol Rev. 2009;33:376-93.

70. Schwartz AR, Potnis N, Timilsina S, Wilson M, Patané J, Martins Jr J, Minsavage GV, Dahlbeck D, Akhunova A, Almeida N, et al. Phylogenomics of Xanthomonas field strains infecting pepper and tomato reveals diversity in effector repertoires and identifies determinants of host specificity. Front Microbiol. 2015;6:535. 
71. Johnson TL, Abendroth J, Hol WGJ, Sandkvist M. Type II secretion: from structure to function. FEMS Microbiol Lett. 2006;255:175-86.

72. Blanvillain S, Meyer D, Boulanger A, Lautier M, Guynet C, Denancé N, Vasse J, Lauber E, Arlat M. Plant carbohydrate scavenging through TonBdependent receptors: a feature shared by phytopathogenic and aquatic bacteria. PLoS One. 2007;2(2):e224.

73. Mole BM, Baltrus DA, Dangl JL, Grant SR. Global virulence regulation networks in phytopathogenic bacteria. Trends Microbiol. 2007;15(8):363-71.

74. Jalan N, Kumar D, Andrade MO, Yu F, Jones JB, Graham JH, White FF, Setubal JC, Wang N. Comparative genomic and transcriptome analyses of pathotypes of Xanthomonas citri subsp. citri provide insights into mechanisms of bacterial virulence and host range. BMC Genomics. 2013;14:551.

75. Murray NE. Type I, restriction systems: sophisticated molecular machines (a legacy of Bertani and Weigle). Microbiol Mol Biol Rev. 2000;64(2):412-34.

76. Low DA, Weyand NJ, Mahan MJ. Roles of DNA adenine methylation in regulating bacterial gene expression and virulence. Infect Immun. 2001; 69(12):7197-204

77. Kim JS, Li J, Barnes IHA, Baltzegar DA, Pajaniappan M, Cullen TW, Trent MS, Burns CM, Thompson SA. Role of the Campylobacter jejuni Cj1461 DNA methyltransferase in regulating virulence characteristics. J Bacteriol. 2008; 190(19):6524-9.

78. Wen Y, Behiels E, Devreese B. Toxin-antitoxin systems: their role in persistence, biofilm formation, and pathogenicity. Pathog Dis. 2014;70:240-9.

79. Gerdes K. Toxin-antitoxin modules may regulate synthesis of macromolecules during nutritional stress. J Bacteriol. 2000;182(3):561-72.

80. Martins PM, Machado M, Silva N, Takita MA, de Souza A. Type II toxinantitoxin distribution and adaptive aspects on Xanthomonas genomes: focus on Xanthomonas citri. Front Microbiol. 2016;7:652.

81. Triplett LR, Shidore T, Long J, Miao J, Wu S, Han Q, Zhou C, Ishihara H, Li J, Zhao $B$, et al. AvrRxol is a bifunctional type III secreted effector and toxinantitoxin system component with homologs in diverese environmental contexts. PLoS One. 2016;11(7):e0158856.

82. Salzberg SL, Sommer DD, Schatz MC, Phillippy AM, Rabinowicz PD, Tsuge S, Furutani A, Ochiai H, Delcher AL, Kelley D, et al. Genome sequence and rapid evolution of the rice pathogen Xanthomonas oryzae pv. oryzae PXO99 ${ }^{A}$. BMC Genomics. 2008;9:204

83. Lee SW, Han SW, Bartley LE, Ronald PC. Unique characteristics of Xanthomonas oryzae pv. oryzae AvrXa21 and implications for plant innate immunity. PNAS. 2006;103(49):18395-400.

84. Lee HM, Tyan SW, Leu WM, Chen LY, Chen DC, Hu NT. Involvement of the XpsN protein in formation of the XpsL-XpsM complex in Xanthomonas campestris pv. campestris type II secretion apparatus. J Bacteriol. 2001;183(2):528-35.

85. Darrasse A, Carrere S, Barbe V, Boureau T, Arrieta-Ortiz ML, Bonneau S, Briand M, Brin C, Cociancich S, Durand K, et al. Genome sequence of Xanthomonas fuscans subsp. fuscans strain 4834-R reveals that flagellar motility is not a general feature of xanthomonads. BMC Genomics. 2013;14:761.

86. Tang JL, Liu YN, Barber CE, Dow JM, Wootton JC, Daniels MJ. Genetic and molecular analysis of a cluster of $r p f$ genes involved in positive regulation of synthesis of extracellular enzymes and polysaccharides in Xanthomonas campestris pathovar campestris. Mol Gen Genet. 1991;226:409-17.

87. Katzen F, Becker A, Zorreguieta A, Puehler A, lelpi L. Promoter analysis of the Xanthomonas campestris pv. campestris gum operon directing biosynthesis of the xanthan polysaccharide. J Bacteriol. 1996;178(14):4313-8.

\section{Submit your next manuscript to BioMed Central and we will help you at every step:}

- We accept pre-submission inquiries

- Our selector tool helps you to find the most relevant journal

- We provide round the clock customer support

- Convenient online submission

- Thorough peer review

- Inclusion in PubMed and all major indexing services

- Maximum visibility for your research

Submit your manuscript at www.biomedcentral.com/submit
Biomed Central 